\title{
Plant vascular development: mechanisms and environmental regulation
}

\author{
Javier Agustí ${ }^{1}$ - Miguel A. Blázquez ${ }^{1}$ (i)
}

Received: 1 August 2019 / Revised: 24 February 2020 / Accepted: 25 February 2020 / Published online: 19 March 2020

(c) Springer Nature Switzerland AG 2020

\begin{abstract}
Plant vascular development is a complex process culminating in the generation of xylem and phloem, the plant transporting conduits. Xylem and phloem arise from specialized stem cells collectively termed (pro)cambium. Once developed, xylem transports mainly water and mineral nutrients and phloem transports photoassimilates and signaling molecules. In the past few years, major advances have been made to characterize the molecular, genetic and physiological aspects that govern vascular development. However, less is known about how the environment re-shapes the process, which molecular mechanisms link environmental inputs with developmental outputs, which gene regulatory networks facilitate the genetic adaptation of vascular development to environmental niches, or how the first vascular cells appeared as an evolutionary innovation. In this review, we (1) summarize the current knowledge of the mechanisms involved in vascular development, focusing on the model species Arabidopsis thaliana, (2) describe the anatomical effect of specific environmental factors on the process, (3) speculate about the main entry points through which the molecular mechanisms controlling of the process might be altered by specific environmental factors, and (4) discuss future research which could identify the genetic factors underlying phenotypic plasticity of vascular development.
\end{abstract}

Keywords Cambium $\cdot$ Phloem $\cdot$ Xylem $\cdot$ Wood $\cdot$ Plasticity

\section{Introduction}

Land plants can be divided into two main groups: those that possess a vascular system (vascular plants) and those that do not (non-vascular plants). This division demonstrates that possessing a vascular system is not an absolute requirement for plants to survive on land. However, it is a clear advantage. Indeed, in evolutionary terms, the appearance of the vascular system was key in the massive colonization of land by plants and represented an enormous impact not only on the biological, but also on the ecological and geological history of our planet.

The first land plants appeared 450 million years ago, evolving from an ancestral charophyceae alga [1]. Two main characteristics of such plants were (1) the rudimentary

Javier Agustí

jagusti@ibmcp.upv.es

$\triangle$ Miguel A. Blázquez

mblazquez@ibmcp.upv.es

1 Instituto de Biología Molecular y Celular de Plantas, CSICUniversitat Politècnica de València, 46022 Valencia, Spain cell-to-cell transporting system that forced them to live, exclusively, in moist zones where water was easily accessible, and (2) their small size. As plants in moist habitats increased in population, fierce competition for water and light began. Two innovations coincided to influence the success in this competition: lignification and the emergence of new interconnected cell types that form the vascular tissue [2]. Lignin, a polymer deposited in cell walls, provides strong rigidity. Lignified cells can resist high water pressure and mechanical stress. As a consequence, the ground was laid to implement efficient long-distance communication systems and to support the weight of larger body sizes without losing stability. With respect to the vascular system, three main tissues are produced in extant plants: the xylem (wood) transporting water and solutes from the soil upwards, the phloem (bark) transporting nutrients and signaling molecules throughout the plant body in multiple directions, and the (pro)cambium, a pool of stem cells programmed to generate xylem and phloem. Xylem and phloem are formed by several cell types, each fulfilling specific functions within each of the tissues. The spatial organization and relative abundance of xylem, phloem and cambium is characteristic 
of each species and of each organ within a given species. The same happens at the tissue-type level: the arrangement and relative abundance of the different cell types that compose the xylem or the phloem are also characteristic of each species and of each organ within a given species [3]. Due to adaptation, ecotypes within a single species usually display fine-tuned versions of such characteristics. Furthermore, developmental plasticity (the capacity to convert environmental inputs to developmental outputs) also adjusts the vascular developmental program of single individuals to the specific environmental conditions encountered during the life cycle [4].

In this review, we first summarize current knowledge about the genetic and molecular mechanisms controlling plant vascular development and phenotypic plasticity and then discuss potential environmental regulation of the process. We argue that understanding the molecular mechanisms by which the environment regulates vascular development may shed light on the adaptive and evolutionary history of the plant vascular system. In addition, we suggest that, by discerning how the environment regulates the molecular control of plant vascular development, we can better understand its plasticity and design biotechnology approaches to adapt vasculature-derived biomass production to climate change.

\section{Vasculature develops throughout the plant life cycle}

From a developmental point of view, it is convenient to distinguish between primary and secondary vascular tissues [5]. The primary vascular tissues, found in all vascular plants, are initially specified when the body plan is establishedduring embryogenesis - and maintained through the activity of the apical meristems during postembryonic development [5] (Fig. 1). Secondary vascular tissues are found in most vascular plant species, although some lineages (i.e., monocots) lost the capacity to develop these tissues during evolution [6].

\section{Establishment and development of primary vascular tissues during embryogenesis}

The first provascular cells are established during the globular stage of embryo development [7] (Fig. 2a). After the embryonic regions giving rise to the aerial or underground parts of the plant are formed, four inner cells within the lower tier of the embryo divide to create a central zone of elongated cells [8]. Eventually, these cells acquire provascular identity in a process that involves a local accumulation of auxin to induce the expression of a central regulator of vascular identity specification: the auxin response factor MONOPTEROS (MP/ARF5) [7-13] (Fig. 2b). The $m p$ mutant is defective in the early divisions of provascular cells and in body axis patterning [10], indicating how vascular specification is intimately connected to embryo development. Strikingly, MP induces the expression of the polar auxin transporter PIN1 [14], likely resulting in enhanced local auxin signaling through a positive feedback loop [13]. The MP inhibitor BODENLOS (BDL) limits MP activity $[14,15]$. BDL belongs to the Aux/IAA family of transcriptional repressors (AUX/IAA12) which, upon auxin accumulation, are degraded by the $26-\mathrm{S}$ proteasome [15-17]. Therefore, auxin-induced MP activation occurs via BDL degradation and the phenotype of the $b d l$ gainof-function mutant mimics that of $m p$ [15]. Thus, to better understand the mechanisms controlling the MP-mediated regulation of vascular specification or the root pole formation (a process also controlled by MP), MP targets (TARGETS OF MONOPTEROS, TMOs) were identified [18]. Among them, TMO3 (previously termed $C R F 2$ [19]), TMO5 and TMO6 were found to be MP-controlled regulators of vascular development. TMO5 is considered a crucial regulator in the process [18]. Through heterodimerization with the atypical bHLH transcription factor LONESOME HIGHWAY (LHW), TMO5 induces LOG3 and LOG4 expression [20], encoding cytokinin (CK) biosynthesis enzymes [21]. Subsequently, CK induces periclinal cell divisions within (pro)cambial cells (Fig. 2b). TMO6 encodes a DOF transcription factor (DOF5.3) that is expressed not only in the provascular embryonic cells [18] but also in the protophloem sieve element in the root [22]. Indeed, TMO6 belongs to the early phloem markers PHLOEM EARLY DOF (PEAR) family [22]. These PEAR factors are of high relevance to prime cambial growth [22]. TMO3 is thought to regulate CK signaling in the embryo $[7,18]$. However, its specific role during vascular development is currently less clear. The involvement of TMO5 and TMO3 in CK biosynthesis and signaling, respectively, is not the only proof of direct CK involvement in embryo provascular tissue establishment and patterning. Indeed, the strong expression of the WOODENLEG (WOL) CK receptor within the embryonic provascular cells also supports this [23]. In brief, the first vascular initials are specified during the globular stage of embryogenesis in a process that involves auxin and CK signaling together with a number of already identified genetic regulators (Fig. 2b).

After specification, the vascular initials proliferate concomitantly with embryonic development. In some species, xylem and phloem can be anatomically identified rather easily at late embryonic stages, but in many others, this is not possible until after germination $[5,8,11]$. In Arabidopsis, embryonic cells displaying overlapping expression of TMO5 and $L H W$ are xylem initials [20]. Given that TMO6 is a PEAR factor, it might be the case that embryonic cells 
Fig. 1 Organization of plant vascular tissues. a Appearance of the provascular tissue at the end of embryo development. b Localization of the procambial, phloem and xylem tissues within primary vasculature in veins and in the root of young seedlings. c Secondary growth in stems. In Arabidopsis (and other dicotyledonous plants), primary vasculature appears in bundles with the phloem facing outwards and the xylem inwards, separated by a layer of procambial cells. Secondary growth requires the sequential formation of a cambial ring between bundles and the stimulation of periclinal cell divisions. d Secondary growth in roots also involves expansion of xylem at the expense of the cambium
A

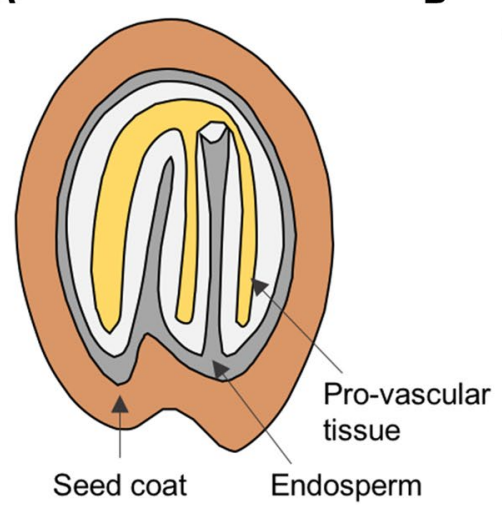

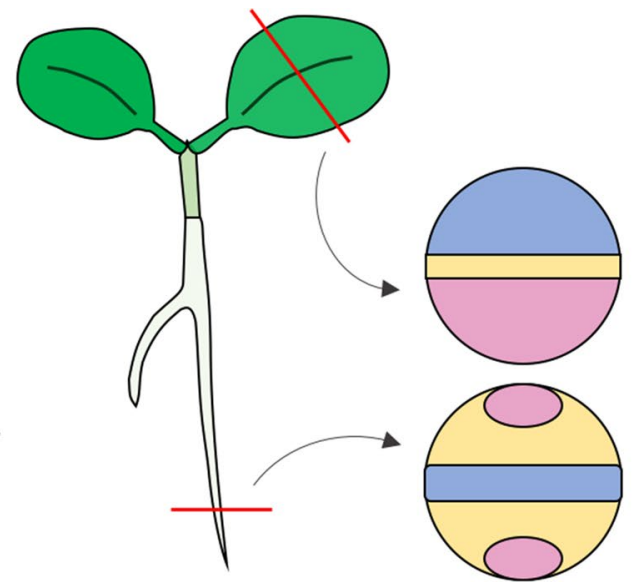

C

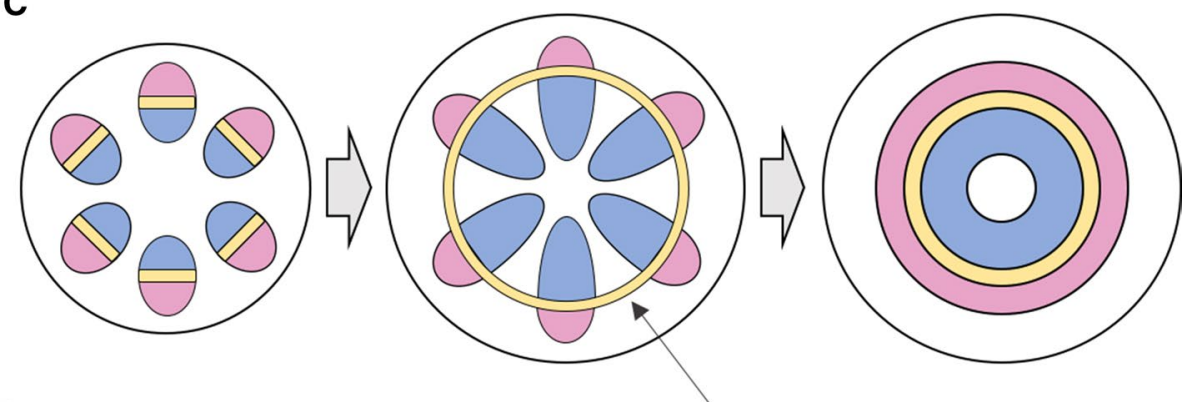

D

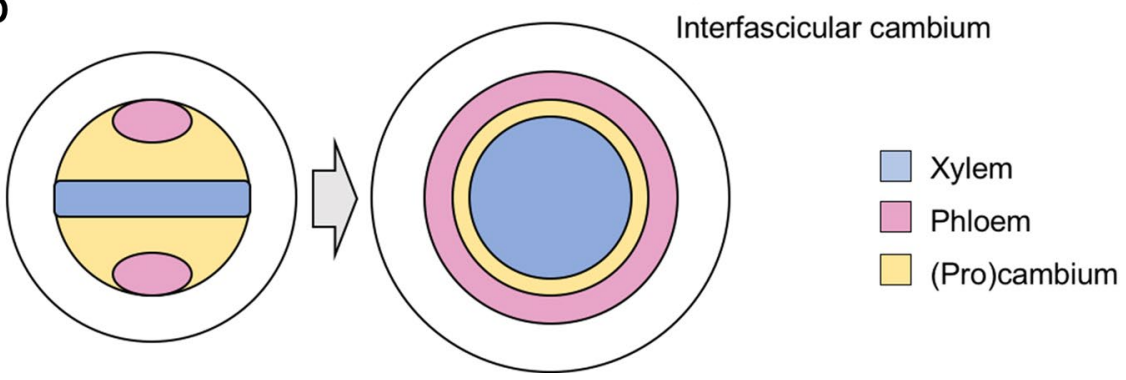

expressing TMO6 are phloem initials, but no functional data are available in this respect.

\section{Postembryonic vascular patterning: roots as model system}

After germination, the primary vasculature that was preestablished during embryogenesis starts maturing, and new vascular tissue forms and develops as the plant grows. Depending on the species, the primary vasculature can organize into different patterns [5]. For simplicity sake, here we will focus on that of the model species Arabidopsis thaliana.

A general trend in all vascular species is that the arrangement of primary vasculature differs between the aerial and the underground organs. In Arabidopsis, the root primary vasculature is structured following a diarch bisymmetric organization $[24,25]$ in which the xylem axis occupies the center (Figs. 1c, 3a). A pole of pholem cells (typically composed of four cells) is found in each extreme of the perpendicular axis to the xylem and procambial cells are located between the phloem poles and the xylem axis. The entire vasculature is surrounded by a layer of pericycle cells [26] (Fig. 3a). At the seedling stage, this organizational pattern expands longitudinally throughout the root and the hypocotyl, connecting the shoot apical meristem (SAM) and the root apical meristem (RAM).

As is the case during embryogenesis, the prevailing models propose that patterning is initially established by the interplay between high CK and high auxin levels, which define distinct domains in the root procambium [27].

\section{Xylem specification}

Metaxylem and protoxylem can be identified by their anatomical position in the root, the metaxylem being composed 


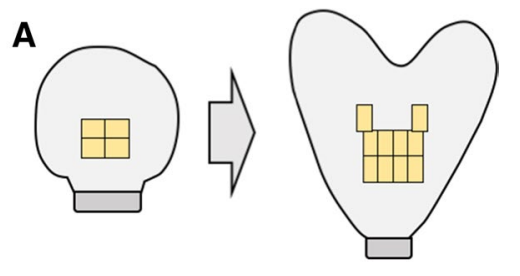

B

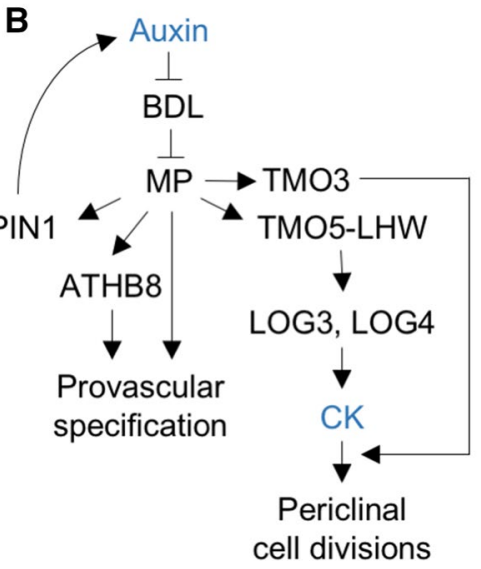

Fig. 2 Mechanism for provascular specification during embryo development. a Illustration of the localization of (1) the initial cells in the globular-stage embryo from which all vascular tissues originate and (2) the periclinal divisions that give rise to additional vascular cells in a heart-stage embryo. b Gene regulatory network that determines vascular cell identity and cell divisions during embryo development. In response to local accumulation of auxin, the MP auxin-dependent transcription factor enhances auxin accumulation through the upregulation of the PIN1 auxin transporter, establishes vascular identity by inducing the ATHB8 HD-ZIP III transcription factor, and promotes periclinal cell divisions via TMO5-LHW-mediated increase in CK synthesis

of three central cells and the protoxylem of the two cells located at each of the poles of the xylem axis [26]. The two xylematic cell types are established through a complex mechanism involving the transcription factors SHORTROOT (SHR) and SCARECROW (SCR) as well as the miRNA165/166, which, in turn, targets the HD-ZIP III transcription factors [28] (Fig. 3b). In this model, SHR is expressed in the procambium and SHR moves to the endodermis. Once there, SHR is recruited to the nucleus, where it interacts with SCR. Such interaction leads to the biosynthesis of miRNA165/166 [28], which also needs basic levels of ABA [29]. The miRNA diffuses to the neighboring cells, creating a miRNA gradient that negatively correlates with HD-ZIP III transcript accumulation and metaxylem identity acquisition. Movement of miRNA165/166 to protoxylem cells causes HD-ZIP III expression to remain low, preventing protoxylem cells from differentiating into metaxylem.

Protoxylem specification is dependent on the expression of the CK signaling inhibitor ARABIDOPSIS HISTIDINE PHOSPHOTRANSFER PROTEIN 6 (AHP6) [23, 30, 31]. AHP6 expression is induced by the LHW-TMO5
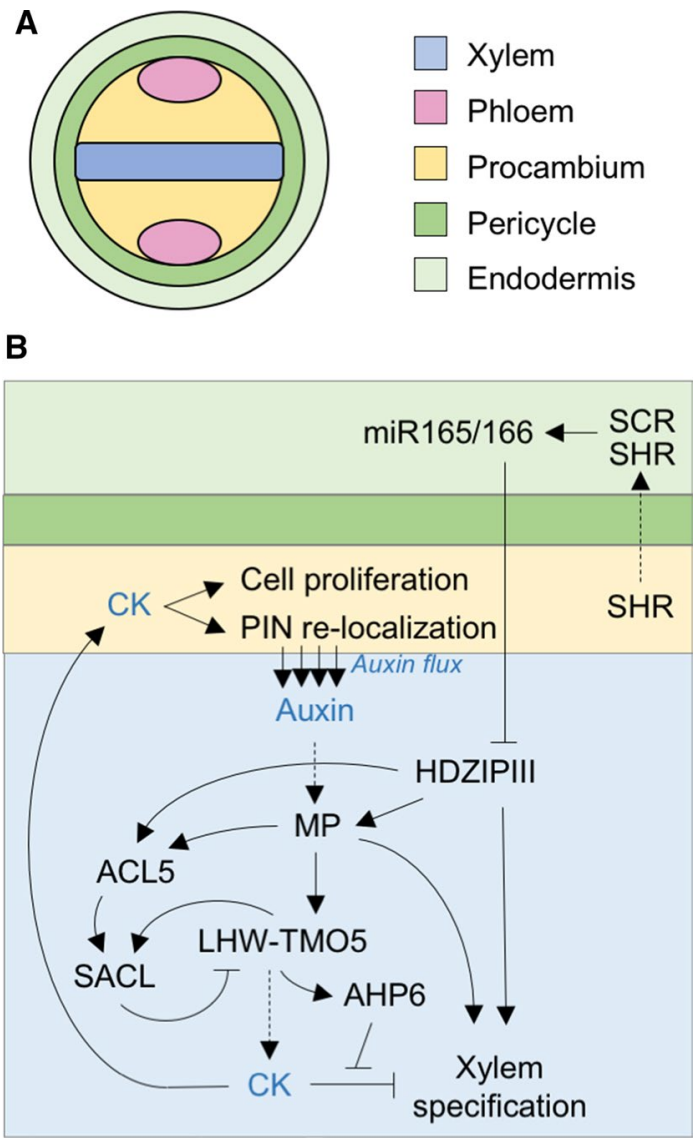

Fig. 3 Mechanism for xylem specification and maintenance in the primary root. a Tissue layer organization surrounding the vascular cylinder of the primary root. The xylem axis in the center is surrounded by vascular-competent stem cells (procambium) and with two phloem poles on opposite ends. b Gene regulatory network that coordinates CK-dependent cell proliferation in the procambium, with auxin-mediated xylem cell-type specification. Xylem specification depends on high local auxin signaling via MP and is also achieved by high HD-ZIP III localization in the xylem precursor cells. MP activity is not only responsible for the attenuation of CK signaling in xylem precursor cells, but also for triggering the ACL5-dependent inhibitory loop that maintains appropriate levels of the LHW-TMO5 complex

heterodimer [32], meaning that it is, at least indirectly, auxin inducible (Fig. 3b). Remarkably, procambial cells adjacent to the xylem facilitate polar auxin transport towards the xylem cells by relocating the PIN polar auxin transporters at the plasma membrane that faces the xylem in a CK-dependent manner (Fig. 3b) [33]. Accordingly, in wol mutants the PIN proteins are mislocalized and protoxylem development is abnormal in pin1 pin3 [34]. $\mathrm{CK}$ is also locally synthesized in the xylem as a result of TMO5-LHW-dependent induction of LOG3 and LOG4 expression, but the auxin-induced expression of AHP6 counteracts CK signaling [35]. In brief, the mutual negative feedback loop of CK and auxin signaling establishes 
and maintains the bisymmetric patterning of root primary vasculature.

Although CK signaling is diminished by AHP6 in xylem developing cells, LHW-TMO5-mediated local CK synthesis is still instrumental to promote the periclinal cell divisions that ensure the continuous supply of new xylem developing cells during postembryonic growth [21]. However, a safety mechanism prevents overproliferation by restricting LHW-TMO5 activity via an incoherent feed-forward loop that operates as follows: first, auxin and the HD-ZIP III factor ATHB8 promote the expression of ACAULIS5 (ACL5, encoding a thermospermine synthase) [36-38]; then, the polyamine thermospermine promotes the translation of the atypical bHLH factors of the SACL family [21, 39, 40], which compete with TMO5 for heterodimerization with LHW, thereby preventing LOG4 induction, reducing CK production, and controlling cellular proliferation. Accordingly, acl5 mutants-in which the LHW dimerization with TMO5 is greatly enhanced-display cellular overproliferation, resulting in aberrant xylem development [41]. This effect is suppressed by overexpression of $S A C L$ genes or by reduction in LHW activity [21]. Ectopic expression of ACL5 in Populus (POPACAULIS5) leads to repression of auxin biosynthesis, although the Populus HD-ZIP III PtHB8 induces POPACAULIS5 expression, suggesting a negative feedback loop between thermospermine biosynthesis and auxin signaling [42]. It is worth mentioning that, even though the only thermospermine function revealed to date is in xylem development, ACL5 and thermospermine are also found in all non-vascular plant lineages [43]. Thermospermine function in such species remains to be elucidated.

\section{Phloem specification}

The MYB transcription factor ALTERED PHLOEM DEVELOPMENT (APL) was the first phloem developmental regulator to be identified [44]. APL acts dually by inducing phloem identity while repressing xylem identity acquirement. Consequently, apl mutants feature xylem elements where phloem should be present. This leads to extremely reduced transport to the root apical meristem and, as a result, a short root phenotype and eventual seedling lethality [44]. However, phloem formation is normal in apl embryos [45], indicating that APL activity is most likely required for the later stages of phloem differentiation. Indeed, the NAC45 and NAC86 transcription factors were shown to act downstream from APL and regulate the activity of particular exonucleases (termed NAC-DEPENDENT EXONUCLEASES, NENs) which mediate enucleation during the last steps of sieve element formation [46]. Approaches through the VISUAL in vitro system, by which mesophyll cells can artificially transdifferentiate into vascular cells (via "intermediate" procambial status), indicated that NAC2O act as a negative upstream regulator of $A P L$ [47]. Recent studies identified the PHLOEM EARLY DOF (PEAR) DOF transcription factors as protophloem sieve elements markers [22]. Functional analyses revealed that PEAR proteins integrate positional information to prime cambial growth [22].

BREVISRADIX (BRX) and OCTOPUS (OPS) are two proteins required for protophloem specification [48-50]. The ops and brx mutants display the same phenotype, both macroscopically (short root) and microscopically (discontinuities within the phloem strand). BRX, which was found through a natural variation approach [49], is auxin inducible. Protophloem differentiation depends on auxin concentration and, recently, it has been reported that BRX interacts with PROTEIN KINASE ASSOCIATED TO BREVISRADIX (PAX) to regulate auxin concentration during protophloem differentiation [51]. Both PAX and BRX locate at the basal zone of cells, where PIN auxin efflux carriers also locate. PAX activates PIN-mediated auxin efflux while BRX dampens it and, at the same time, PAX mediates BRX efficient plasma membrane localization, which is also negatively regulated by auxin. BRX inactivates PAX through direct interaction [51]. High auxin intracellular concentration induces PAX activity, leading to enhanced PIN-mediated auxin efflux, which depletes the cell of auxin, permitting BRX to associate with the plasma membrane and inactivate PAX, blocking PIN activity and, thus, favoring intracellular auxin accumulation [51]. Therefore, BRX and PAX are members of a molecular rheostat that modulates auxin flux during protophloem differentiation [51]. Protophloem specification is negatively regulated by a signaling pathway mediated by the leucine-rich repeat receptor-like kinase (LRR-RLK) BARELY ANY MERISTEM 3 (BAM3), whose activity depends on the binding to its ligand (the small peptide CLE45) in a dose-dependent manner [50]. $B R X$ restricts the expression of BAM3 [52] and the negative effect of the signaling, activated through CLE45 binding to BAM3, is amplified by MEMBRANE-ASSOCIATED KINASE REGULATOR 5 (MAKR5), which acts downstream from BAM3 [53]. Recently, it was shown that the positive regulation of the protophloem specification mediated by OPS acts as an insulator against CLE45 signaling by interfering with its binding to BAM3 [54].

Through a screen for brx suppressors, COTYLEDON VASCULAR-PATTERN 2, was identified [55]. Mutants for such gene accumulate abnormal levels of phosphoinositol and display discontinuous protophloem cell files in the root [55]. This and subsequent research indicate that phosphoinositides levels are important for the differentiation of protophloem [56]. Furthermore, the SUPPRESSOR OF MAX2 1-LIKE 3 (SMXL3), SMXL4 and SMXL5, which were found to be strigolactone (SL)- and karrikin-independent, control protophloem specification in a redundant manner, since the double (smxl4 smxl5) and, specially, the triple smxl3 smxl4 
smxl5 mutants, but not the single ones, show discontinuities in the root phloem strands and reduced root length [57].

\section{Leaf venation}

From germination until floral transition (when the floral stem is developed), the only aerial organs found are cotyledons and leaves. In such flat organs, the vasculature is organized in so-called veins, which constitute a continuous, connected, reticulated system of vascular bundles. In these bundles the xylem usually faces the adaxial (upper) part of the leaf and the phloem, the abaxial (lower) part. The pattern formed by the veins is usually called venation and is characteristic of lineages and species. For example, monocots usually feature a parallel organization of their venation, while dicots often develop a reticulated structure [58].

A fundamental characteristic of the leaf vascular system is the close spatial relationship between the mesophyll (the photosynthetic cells) and the actual vascular tissues [5]. Physiologically, this is of great relevance, since photosynthesis implies water loss (which needs rapid supply by the xylem) and the production of photoassimilates that must be transported through the phloem.

In cotyledons and leaves, the vascular tissue starts developing as soon as the primordium is established. Preprocambial tissue differentiates from ground cells when the leaflet emerges and continues maturing into procambium, while the leaf expands and matures into a fully developed organ. In accordance with the auxin canalization model summarized by Sachs $[59,60]$, auxin signaling locates in specific ground cells that subsequently give rise to the veins even before they are anatomically different to their neighboring cells [61]. Both early induction of the auxin response factor $M P$ in these cells $[13,62]$ and the discontinuity of vascular strands in $m p$ mutants [10] suggest an early function of MP in leaf vein formation. The auxin efflux carrier PIN1 accumulates in the same preprocambial cells in which $M P$ expression is detected, and which, later on, will define the vein pattern [13]. Interestingly, in $m p$ mutants, the PIN1-GFP signal is greatly reduced and only detected in the cells where $M P$ expression remains, implying that the MP-mediated auxin signaling precedes PIN1 accumulation [13].

In the initial steps of leaf primordia development, $M P$ expression and PIN1 accumulation are widespread [63]. Gradually, both get confined to narrow regions in a process mediated by the activity of the HD-ZIP III transcription factor ATHB8 [63]. In brief, the preprocambial cells are determined and become specialized for PIN1-mediated auxin transport in a MP- and ATHB8-dependent manner. In turn, since $M P$ expression is stimulated by auxin, the PIN1mediated auxin transport leads to enhanced MP and ATHB8 activity in a feedback loop [62, 63].

\section{Vascular bundle formation in stems}

In Arabidopsis, the elongation of the floral stem starts upon the transition to the reproductive phase. Primary vasculature in stems develops in the form of discrete, not interconnected, vascular bundles that are distributed radially (Fig. 1c). In Arabidopsis, stems typically develop between five and eight vascular bundles in which the phloem faces the external part of the stem and the xylem, the internal one. Between xylem and phloem, the number of procambium cell layers can vary. Procambial cells give rise to extra xylem or phloem depending on the plant's necessities. Furthermore, these cells are key in the initiation of secondary vascular tissue growth (see below). To date, little is known about how vascular bundles are determined and patterned. While the HD-ZIP III transcription factors are key to establish the xylem and phloem polarity [64], the relative position of phloem and xylem is controlled, at least partly, by the signaling pathway mediated by the LRR-RLK PHLOEM INTERCALLATED WITH XYLEM (PXY)/TDIF RECEPTOR (TDR) [65, 66]. The dodeca-CLE peptides TDIF/CLE41/42/44 are synthesized in the phloem and then move to the procambium, where they meet their receptor, PXY, activating a signaling cascade that controls the xylem/phloem relative position [65-69] (see below). It is thought that such control on patterning might occur through an interaction with ERECTA [67, 68].

The stem vascular bundles function is double: they provide an apical/basal axis to transport water, solutes, nutrients and signaling molecules, and they serve to connect the stem with the veins of the lateral organs [70].

\section{Vascular cell differentiation}

Xylem is mainly formed by conductive cells known as "tracheary elements" (TEs). In gymnosperms, the TEs are called tracheids. Such tracheids fulfill two roles: support and transport. In eudicots, two TEs cell types can be found, each with specialized functions and anatomy: the vessels, specialized in water and solutes transport, and the fibers, specialized in providing mechanical support and stability [5]. Vessels and fibers undergo secondary cell wall formation, lignification and programmed cell death (PCD) during their maturation [71].

Vessels start forming at very early stages of xylem development (Fig. 4). The NAC transcription factors VND6 and VND7 are fundamental for the formation of this cell type [72] (Fig. 5). The timing for fiber initiation is controlled by ERECTA (ER) and ERECTA-LIKE1 (ERLI) in a GAdependent manner [73]. In order for the cambium and developing xylem cells to become sensitive to GA and, therefore, differentiate fibers instead of parenchyma, the activity of the class I KNOX transcription factor KNAT1/BREVIPEDICELLUS (KNAT1/BP) is needed [73, 74]. Indeed, KNAT1/ 
Fig. 4 Cell differentiation pathways which produce the diverse phloem and xylem cell types. Illustration of the formation of different phloem and xylem cell types from unique vascular stem cells. Xylem cells include the dead vessels (tracheary elements) and fiber cells with extensive secondary cell wall deposition, along with live xylem parenchyma cells. Phloem is composed of the sieve elements and the phloem companion cells. Pink circles depict cell nuclei, and white ellipses are vacuoles

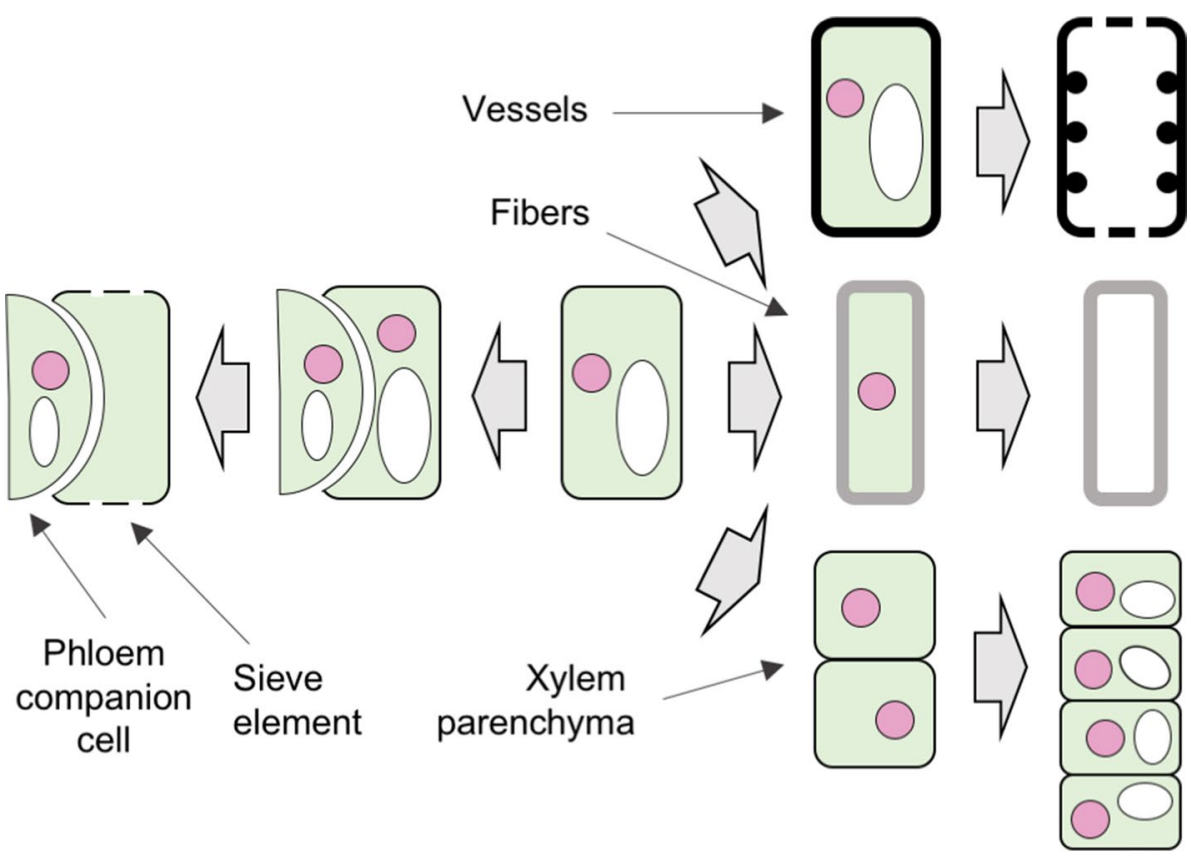

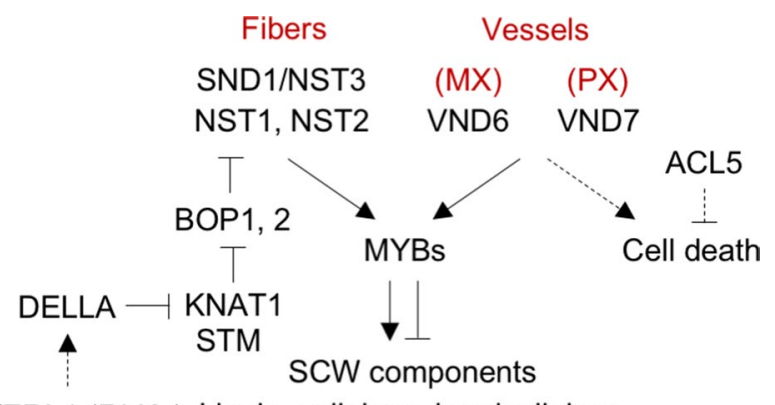

ER/ERL1 (RLKs) Lignin, cellulose, hemicellulose

Fig. 5 Gene regulatory network for the differentiation of xylem fibers and the two types of vessels. The different cell identities are established by specific expression of VND6 (metaxylem, MX), VND7 (protoxylem, PX), and SND1/NST3 (fibers) transcription factors. SCW synthesis is regulated by the second tier of MYB transcription factors, while programmed cell death is regulated by the ACL5 thermospermine synthase. Additionally, fiber formation is absolutely dependent on STM and KNAT1 activity and this is stimulated by low DELLA levels achieved by high GA production, which is thought to be regulated by receptor-like kinases such as ER and ERL1

BP activity has been shown to be negatively regulated by DELLA through physical interaction [75], and $b p$ mutants do not display fiber formation [76]. Such a defect cannot be rescued by GA application [75]. Recently, research has shown that the leucine-rich repeat receptor-like kinase SUPRESSOR OF BIR 1/EVERSHED (SOBIR1/EVR) prevents the precocious initiation of xylem fiber differentiation by a mechanism that involves BP and ERECTA [77]. BP binds the promoter of $S O B I R I / E V R$, and SOBIRI/EVR expression is diminished in $b p$ mutants, indicating a negative effect of BP on the expression of SOBIRI/EVR [77]. Furthermore,
SOBIR1/EVR physically interacts with ERECTA and the effect of sobirl/evr mutation on the initiation of fiber differentiation is enhanced in erecta mutant backgrounds [77]. BP activity in fiber development occurs by activating the expression of $N S T 1$ and $N S T 3 / S N D 1$, two master regulators of fiber formation [76]. NST1 and NST3 are found upstream from BLADE ON PETIOLE 1 (BOP1) and/or BOP2, with which KNAT1/BP genetically interacts [76], implying that $B O P 1$ and $B O P 2$ might be highly relevant for fiber differentiation. Although the $n s t 1, n s t 3$ and even $n s t 1$ nst 3 double mutants do not show any obvious defective phenotype, NSTs are expressed in xylem cells undergoing secondary cell wall biosynthesis and the overexpression of NST1 or NST3 leads to ectopic xylem fiber formation [78, 79]. While BP controls the expression of SOBIRI/EVR, the interaction between SOBIR1/EVR and ERECTA controls KNAT1/BP levels by reducing GA signaling [77]. Presumably, this occurs by enhancing the levels of DELLA, which would limit KNAT1/ $\mathrm{BP}$ activity through direct interaction. Thus, SOBIRI/EVR transcription would also be limited and a feedback loop that would maintain KNAT1/BP abundancy and, as a result, NST activity in check, would be generated [77].

The function of VND6, VND7, NST1 and NST3/SND1 is conserved across angiosperms [80]. Large-scale yeast-one hybrid analyses identified numerous targets of such transcription factors [81]. Indeed, the authors used these results to construct a network regulating secondary cell wall formation during xylogenesis [81].

In addition to TEs, many species develop xylem parenchyma: a cell type that remains alive, stores reserves in the form of starch and provides physiological support to TEs during and after their maturation. To date, our knowledge 
about the mechanisms by which such xylem parenchyma cells develop is scarce.

\section{Regulation of cambial activity and secondary growth}

Secondary vascular tissues develop radially in stems, roots and hypocotyls in a process known as secondary growth which results in thickening. Secondary growth provides enhanced transport capacity as well as mechanical support and stability. In Arabidopsis hypocotyls, secondary xylem development resembles that of trees and, therefore, this organ has become a reference for research in secondary growth development in general and secondary xylem development in particular [82]. Secondary xylem occurs in two phases in Arabidopsis hypocotyls: phase I in which vessels and parenchyma (but not fibers) are formed and phase II, in which no parenchyma is formed, but vessels and, especially, fibers differentiate massively [82]. The transition from phase I to phase II is coordinated with flowering and is mediated by the activity of gibberellic acid, which is precisely synthesized during flowering [83].

Secondary growth occurs through the activity of the vascular cambium, a meristem that is found in a ring-like domain, internally to stems, roots and hypocotyls [84]. In Arabidopsis, the vascular cambium forms differently in the stem, the hypocotyls and the root. In the stem, the vascular cambium develops through two complementary processes: the lateral expansion of the procambial cells located between xylem and phloem in the vascular bundles and the formation of new cambial cells through proliferation and transdifferentiation of the interfascicular regions of the starch sheath, the innermost cortical cell layer in stems [4, 84] (Figs. 1c, 6a). However, in the hypocotyl and the root, there is no transdifferentiation and, indeed, the vascular cambium arises from massive cellular proliferation of the procambial and a few pericycle cells $[26,85]$. Soon after the onset of this proliferation, cells in contact with the primary xylem start differentiating into secondary xylem [85]. Subsequently, more cambial cells in contact with the new xylem cells also start differentiating into secondary xylem. The process goes on to result in an accumulation of secondary xylem in the central part of the root and the hypocotyl. This new xylem forces the cambium towards the external part in a radial manner, leading to the formation of the classical cambial ring. In later stages, the cambium develops secondary phloem, which also organizes as a ring [24] (Fig. 1d).

Similar to that described above for the vascular bundle development, PXY also controls both the relative disposition of the xylem and phloem during secondary growth [65]. In addition, PXY controls the proliferation of cambial cells as well $[65,67]$ (Fig. 6b). The PXY-mediated control of

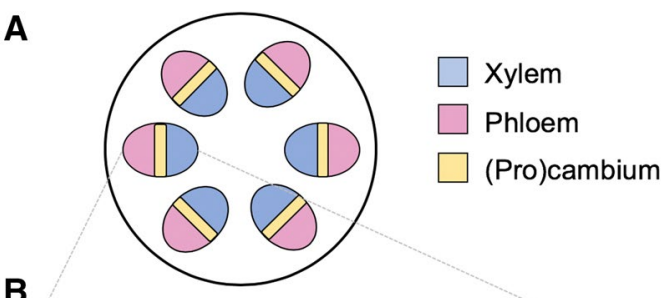

B

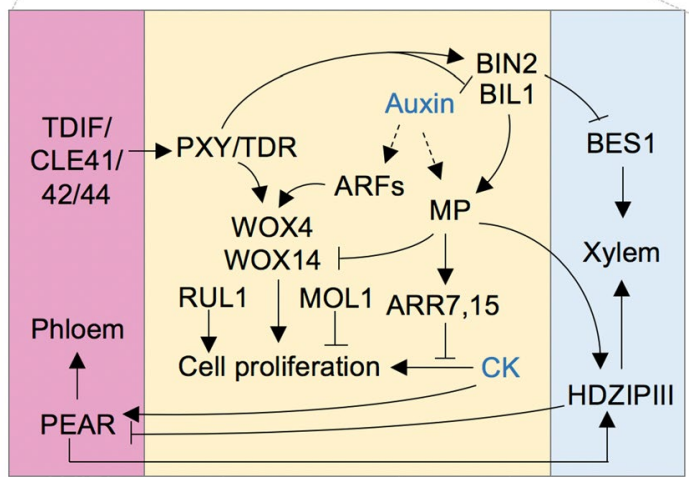

Fig. 6 Regulatory mechanism of cambial activity and secondary growth. a Scheme of stem vascular bundles showing the bifacial cambium. b Gene regulatory network coordinates cambial cell proliferation and the production of phloem and xylem on opposite sides of the cambium. This organization is the result of several regulatory interactions: (1) the PXY receptor-like kinase is activated by the phloemgenerated TDIF signal (CLE41, 42, 44 peptides) and induces the WOX transcription factors which, in turn, promote cell proliferation in the cambium; (2) auxin modulates cell proliferation with opposing effects that involve the attenuation of CK signaling and the upregulation of WOX genes; (3) xylem specification is promoted by the PXYdependent repression of brassinosteroid signaling and by the positive effect of auxin on HD-ZIP III expression in xylem precursor cells; (4) phloem is regulated by the mobile PEAR transcription factors that are upregulated by $\mathrm{CK}$ in the cambium

cellular proliferation occurs by activating the WUSCHEL RELATED HOMEOBOX 4 (WOX4) and WOX14 proteins $[65,67]$. The pathway is conserved between Arabidopsis and Populus [86]. Independently of PXY, two more receptor-like kinases (RUL1 and MOL1) play opposing roles to regulate cambial cell proliferation, RUL1 being a positive and MOL1 a negative regulator in the process [84] (Fig. 6b). Recently, it was shown that the glycogen synthase kinase 3 BIN2-LIKE1 (BIL1) phosphorylates MP, which acts as a negative regulator during secondary growth by upregulating CK signaling repressors [87]. The phosphorylated MP enhances its negative activity [88]. However, PXY inhibits BIL1, maintaining secondary growth in homeostasis [88]. In brief, these results demonstrate that BIL1 connects peptide signaling with auxin/cytokinin signaling [88] (Fig. 6b).

Which molecular mechanisms lead cambial cells to enter the phloem or xylem developmental programs is still an open question. Strikingly, a recent and elegant report based on linage tracing and molecular genetics discovered 
a role for cells with newly acquired xylem identity within the cambial zone as organizer/quiescent center for the cambium directing adjacent cambial cells to divide [89]. This is dependent on auxin concentration and expression of HD-ZIP III factors and the quiescent center also maintains phloem identity in a non-cell autonomous manner [89]. Remarkably, it is within the early protophloem-sieve-element cell files of the procambial tissue where radial growth begins [22]. In such cellular domain, CK induces the expression of the above-mentioned PEAR1 and PEAR2 and their four homologues DOF6, TMO6, OBP2 and HCA2. Short-range movement of the PEAR proteins establishes a concentration gradient that is key for the initiation of radial growth [22]. Interestingly, the PEAR proteins promote the transcription of the HD-ZIP III factors, which antagonize the activity of the PEAR proteins, establishing a negative feedback loop [22]. Thus, the module created by the CK-induced PEAR and auxin-induced HD-ZIP III transcription factors integrates the spatial information and hormonal signaling in the definition of the quiescent center and cells that are actively dividing, which is fundamental for radial growth [22, 89]. Auxin action on cambial activity is well established [90]. Indeed, auxin peaks were found in cambium in Populus and Arabidopsis and auxin signaling is enhanced in parenchymatic tissues transforming into interfascicular cambium [91-96]. Accordingly, in vitro auxin treatment on isolated immature Arabidopsis stems led to interfascicular cambium formation [84] and both Populus and Arabidopsis undergo reduced secondary growth when auxin signaling is reduced, as is the case in mutants such as axrl [91-96]. However, the regulation seems to be more complicated, since different AUXIN RESPONSE FACTORS (ARFs) seem to play different roles and, while ARF3 and ARF4 stimulate cambium activity, ARF5 (MP) counteracts such induction, suggesting an auxin-controlled, ARFs-mediated homeostasis of cambial activity [87].

Auxin signaling also results in the induction of WOX4 activity independently of PXY - although PXY is required to keep the induction stable over time, as deduced from unstable auxin-induced WOX4 expression in pxy mutants-indicating that auxin-induced cambial activity does not require PXY signaling [97]. Auxin transport plays a central role in cambium activity $[98,99]$ and, indeed, at least pinl and pin3 mutants undergo reduced cambium activity, reflected in decreased secondary growth in Arabidopsis [100]. As in the case of other developmental processes, auxin interacts with strigolactones (SLs) to regulate secondary growth; moreover, genetic, molecular and physiological analyses proved that SLs act downstream from auxin to control the process, adding a new step in the hormonal regulation of secondary growth initiation [100].

CKs are known to stimulate cellular proliferation in meristems [7]. In cambium, several reports indicate a clear correlation between CK signaling and cambial cell proliferation both in Arabidopsis and Populus [101]. The abovementioned heterodimerization of LHW with TMO5, leading to CK biosynthesis via $L O G 3$ and $L O G 4$ expression [21], is also crucial to stimulate cellular proliferation during radial growth. Recently, DOF2.1 was found to control such cellular proliferation downstream from the LHW-TMO5 heterodimer [102].

As explained above, gibberellins are essential for the formation of xylem fibers, which are associated to the expansion phase of secondary growth [82]. Thus, they play a positive role in wood accumulation, thereby positively regulating secondary growth [103]. Jasmonic acid [104], ethylene [104, 105] and ABA [106] have also been shown to play a positive role in secondary growth.

Little is known about the regulation of secondary phloem formation (Fig. 4). However, it is known that most of it is parenchyma and that a few sieve elements and companion cells arise randomly through it.

\section{Environmental regulation of vascular differentiation}

Vascular development is modulated by an array of environmental factors, ranging from temperature and light regimes to water availability, mechanical stress, or salt concentration in the soil. While light and temperature signals are interpreted mostly as seasonal cues by plants, other factors may represent transient, adverse situations that challenge the plant's ability to acclimate. In those cases, plasticity in vasculature development is part of an integral plan to optimize the use of resources. As described below, acclimation strategies include the alteration of cambial cell proliferation rates, xylem to phloem proportion, relative abundance of specific cell types within xylem or phloem, and the patterns and/or properties of such cell types, including cell wall thickness, cell length, cell diameter, cell wall pitting or cell wall reticulation. It must be noted that, in the case of xylem, fully differentiated cells are dead, preventing any post-developmental plasticity [107]. Therefore, xylogenesis plasticity must occur entirely during xylem specification and differentiation and cell properties of fully developed xylem cells are not reversible. Consequently, the environmental conditions during xylogenesis are critical for the general performance of plants.

\section{Drought}

Water is absorbed by roots and transported acropetally through the plant by the xylem water conduits: vessels in angiosperms and tracheids in gymnosperms [108]. Thus, water availability constitutes an essential environmental 
input for xylogenesis plasticity, the result of which is crucial for plant acclimation to drought. Mechanisms underlying such xylogenesis plasticity for acclimation to water availability require hormone activity (Fig. 7). In this regard, the role of ABA is the most frequently studied one, although CK and JA have been shown to play important roles as well.

Drought is known to enhance the biosynthesis and accumulation of ABA [109]. Among other actions, ABA regulates various aspects of the differentiation and patterning of primary and secondary xylem $[29,106]$. ABA treatments in Arabidopsis roots induced extra meta and protoxylem cells, the latter with reticulated, rather than pitted, secondary cell walls [29]. By contrast, abi2-1 and abi3-1 mutants, impaired in the last steps of ABA biosynthesis, displayed discontinuous or absent xylem strands [29]. An effect very similar to the abi2-1 and abi3-1 mutations was observed when WT was treated with the ABA biosynthesis inhibitor fluridone [29]. Further, provascular and endodermis cellular differentiation was accelerated in ABA-treated roots in both Arabidopsis and Tomato [110]. The mechanism by which $\mathrm{ABA}$ regulates the determination of the xylem cell types is non-cell autonomous [29]. Indeed, it occurs in the endodermis, where ABA induces miRNA165/166 biosynthesis while reducing the expression level of the miRNA165/166

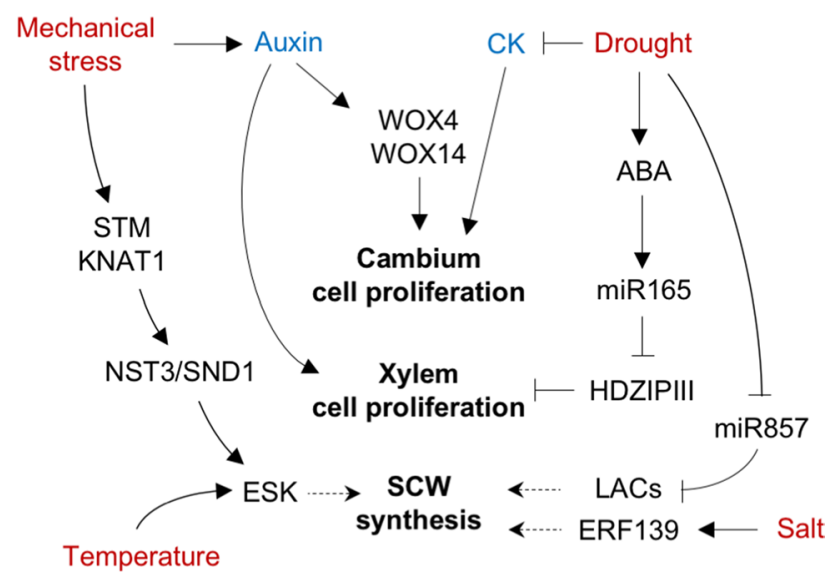

Fig. 7 Possible mechanisms for environmental regulation of vascular development. Three processes have been reported to be under environmental control: (1) cell proliferation in the cambium, which is inhibited by drought via the reduction in root-to-shoot CK transport, and stimulated by mechanical stress via auxin upregulation; (2) proliferation of xylem cells to increase water transport potential or counteract possible consequences of vessel cavitation; this is activated by drought through the ABA-dependent upregulation of miR165 (allowing for the reduction in HD-ZIP III activity), and also by mechanical stress in an auxin-dependent manner and (3) the production of secondary cell wall components, which is increased by drought and salt through the upregulation of specific cell wall enzymes; moreover, the relative composition of SCW material is also modulated by mechanical stress (with an increase in fiber cell production) and by temperature (which affects the activity of ESK, an enzyme that modifies xylan) repressor ZWILLE/ARGONAUTE 10 (ZLL/AGO10) [29, $110]$. The miRNA165/166, as mentioned above, moves to the developing xylem cells, and its levels determine the proto- or metaxylem identity by controlling the mRNA accumulation of certain HD-ZIP III factors [28]. Accordingly, ABA treatments failed to induce extra xylem strands in miRNA165/166 resistant lines such as phbl-d or in mutants with considerably reduced miRNA165/166 accumulation such as $s c r$ or $s h r$ [110]. Drought treatments-shown to induce ABA in roots $[111,112]$ affected miRNA165/166 levels and led to the same phenotypic effects induced by ABA, linking drought with the ABA-mediated mechanism of regulation in miRNA165/166 levels to control xylem celltype specification [29].

In trees, long-term drought reduces secondary growth and modifies the pattern of vessel formation [113, 114]. Despite reducing general levels of secondary growth, drought induces the formation of extra vessel cells with reduced cellular diameter $[113,114]$. Thus, this response represents an acclimation mechanism to drought that diminishes cavitation without losing vessel transport capacity $[113,114]$. This alteration seems to be maintained, at least partially, across seed plants, since tracheid diameter in the gymnosperm Picea abies was also smaller in individuals subjected to severe drought [115]. Further observations also indicated drought-induced increase in vessel cell wall thickness, at the expense of the vessel lumen [116], which results in reduced conducting surface. The precise mechanism that regulates cell wall deposition in response to stress is not understood, but experiments with Arabidopsis in which osmotic stress was stimulated by high mannitol content in the growth medium [117] revealed a substantial decrease in microRNA857 abundance. Given that miR857 is a posttranscriptional inhibitor of $L A C 7$, which encodes a laccase involved in lignin deposition in the secondary xylem [118], the drought-mediated regulation of the machinery controlling cell wall properties is likely to be a widespread mechanism to modulate xylem conduits properties under drought. This view is also supported by work with $P$. trichocarpa, in which drought differentially affected the expression of a large number of genes involved in cell wall remodeling, including four master switch regulators orthologous to the Arabidopsis NST1 transcription factor, and 29 laccaseencoding genes [119].

Drought has also been shown to reduce secondary growth by hampering the accumulation of $\mathrm{CK}$ and its root-to-shoot transport [120-122]. Decreased levels of CK in well-watered plants increased ABA sensitivity [122], suggesting a crosstalk between the two hormones. Moreover, jasmonic acid (JA) is thought to induce xylem differentiation in Arabidopsis roots from meristematic procambial cells by counteracting the CK-dependent promotion of cell division [123]. Given that JA signaling is necessary for consistent ABA 
accumulation in roots in response to water limitation [124], current knowledge indicates that the interplay between ABA, JA and CKs modulates xylem differentiation as part of the acclimation strategy to varying water levels.

\section{Salt stress}

Although the effects of high salinity on vascular development are similar to those caused by drought, there are indeed differences in the responses of plants to each type of stress. For example, while drought induced extra protoxylem differentiation [29], this effect was not observed in roots grown under high salinity, even when incubating plants in increasing $\mathrm{NaCl}$ concentrations [110]. This observation constitutes a clear difference between the responses of plants to drought or salt stress in terms of vascular development. Therefore, it is plausible that salt stress, while inducing ABA biosynthesis, might trigger some signaling pathway preventing extra protoxylem differentiation. On the other hand, like drought, salt stress has been shown to reduce lumen in xylem vessels in Arabidopsis, tomato and Populus [125]. This reduction in overall xylem lumen development seems to be necessary to enhance salt tolerance, since the acl5 Arabidopsis mutants, with excessive, premature, xylem development, display salt hypersensitivity [126]. Several possible mechanisms may be responsible for this effect. For instance, the reduction in xylem vessel volumes in poplar trees subjected to 2-week salt treatments was associated to an increase in ABA levels in leaves, which caused stomata closure and subsequent diminished nutrient uptake by the cambium, causing indirectly the decrease in vessel lumina [127]. Alternatively, enhanced lignin deposition has been observed in developing xylem vessels of plants growing under high salinity in Aeluropus littoralis as well as in tomato roots [128, 129]. To support this hypothesis, studies have focused on two transcription factors whose expression is induced by salt and whose overexpression promotes secondary cell wall deposition during xylem differentiation: ERF 139 in Arabidopsis [130] and BplMYB46 in birch [131].

\section{Temperature}

The most widely studied effects of temperature on vascular development are those associated to the alteration of cambial cell proliferation and secondary cell wall deposition in xylem cells. In seasonal climates, the main environmental factor affecting cambial activity is temperature. This is reflected by the correlation between the timing of cambial reactivation after dormancy and the early onset of the growth season [132]. Studies in Populus revealed extensive transcriptomic and proteomic changes in the cambium during the activity-dormancy cycle [133]. More importantly, these changes included the activation of cell cycle genes during cambium activity and their repression during dormancy. These changes are primarily temperature-dependent, according to water culture experiments, which show that PtoCDKB and $P$ to CYCB transcripts are clearly expressed in cambium at warm temperatures but undetectable at low ones [134].

Given that cold induces MT de-polymerization in plant cells [135], it was thought that temperature-mediated cambial activity regulation might depend on the MT polymerization state [132]. However, it is not clear whether changes in MT polymerization are the cause or a readout of cambial activity state. Indeed, MT de-polymerization has been observed in the cambium when temperatures transiently descended during the warm growth period [132], but transient warm temperatures during the winter dormancy period did not re-polymerize MT [132]. By contrast, the detection of enhanced accumulation of transcripts encoding MT-associated proteins (i.e., MAP20) in Poplar during the formation of secondary cell walls suggests the involvement of MT in vascular development [136].

Arabidopsis leaves have been shown to acclimate to high temperatures by increasing vein density [137]. This response might be related to a general shift from sugar transport at cool temperatures to water transport through tracheary elements at warmer temperatures, perhaps due to enhanced transpiration. Intriguingly, the expression of the $P X Y$ paralog encoded by AtPXL1 is patently induced both by cold and heat stress and the atpxll mutant line showed a temperature hypersensitive phenotype [138]. These results suggest that PXY activity at the cambium might be important for acclimation when temperatures fluctuate. It remains to be seen whether temperature can control $P X Y$ expression or PXY activity or whether there is a yet-to-be discovered PXY upstream regulator whose activity is temperature dependent.

As mentioned above, temperature is also a major modulator in the composition of xylem secondary cell walls, as shown by work with ESKIMOI, a gene encoding a 2-O- and 3-O-acetyl transferase that targets xylosyl residues in xylan [139]. ESK1 expression is regulated by the secondary cell wall regulator SND1/NST3 and, accordingly, its expression is stronger in vascular tissues than in other tissues, especially in cells undergoing xylem differentiation [140]. Vessels collapse in the loss of function eskl mutants. However, the mutation allows resistance to freezing and cold temperatures in general as well as to salt stress [141]. The defects in $e s k 1$ xylem vessels appear to be linked to a reduction in esterified pectins, which is in agreement with the observed downregulation of a gene encoding a pectin methylesterase inhibitor in the esk1 mutant [140].

\section{Mechanical stress}

The proliferation of cambial cells and the differentiation of the cell types that form the xylem and the phloem 
occur in the context of intense mechanical forces [104]. On the one hand, tensions originate from endogenous processes, such as the increasing weight of the plant from growth, the pressure caused by the proliferation and accumulation of new cells or the changes in turgor caused by cell differentiation or water conductance through tracheids or vessels. On the other hand, external environmental conditions, including wind or the presence of obstacles in the growth axis, also generate mechanical forces. Due to lignification, the vascular cells can counteract such mechanical stress. Therefore, a common response of plants to mechanical forces is the generation of new vascular cells. In other words, mechanical stress induces vascular development. A clear example of this is the stimulation of secondary growth as a response to increased plant weight [98]. Such response has been shown to be accompanied by the enhanced expression of secondary cell wall regulatory genes [142], changes in the expression of auxin signaling elements and stimulation of polar auxin transport [98]. However, despite the dominant role of auxin in weight-induced secondary growth, other factors (perhaps some of them auxin-independent) also contribute to controlling the mechanical stimulation of secondary growth. For example, ABA, ethylene and JA signaling are induced during secondary growth in Arabidopsis and control several aspects of the process, most likely in an auxin-independent manner [104-106]. Additionally, ethylene was found to control cambial cellular proliferation both in normal conditions and during tension wood development in Populus [143]. During the process, no change in auxin levels was found in tension wood forming tissues [144], although the establishment of an auxin gradient - most likely led by auxin redistribution-seems to be necessary [145]. Furthermore, GA was shown to control all major aspects of tension wood formation when applied to Populus stems [146] and a role for it during the process cannot be excluded. As previously discussed, KNAT1/BP regulates xylem fiber production [76]. SHOOT MERISTEMLESS (STM), another class I KNOX transcription factor, was found to act redundantly with BP in this process [76] and its expression is induced when there is mechanical stress in the shoot apical meristem [147]. The expression of SOBIRI/EVR, which, as described above, participates in the BP-mediated mechanism regulating fiber formation, was enhanced in the cambium upon mechanical stress induction [98]. All in all, current knowledge suggests a potential scenario in which the mechanical stimulation of secondary growth may act through auxin-dependent pathways regulating cambial cell proliferation and parallel auxin-independent pathways to control specific aspects in the differentiation of the vascular cell types.

\section{Conclusions and future prospects}

In recent decades, our understanding of the genetic and molecular control of vascular development has increased considerably. In parallel, work with both herbaceous and woody species has revealed the effect that environmental factors have, anatomically, on the vascular tissues. Therefore, studies should now focus on identifying the molecular mechanisms underlying the environmental modulation of vascular development. Previous attempts to connect vascular development with environmental factors have been based mostly on field studies with woody plants, often comparing species. Given the relatively high level of understanding of the molecular mechanisms involved in vascular development in model plants, like Arabidopsis and Populus, it seems necessary to approach the study of all aspects of vascular development under the controlled combined action of different environmental signals. Such an approach is likely to identify "entry points" through which each environmental factor alters the molecular control of vascular development.

Classical forward genetic screens are extremely tedious when performed for vascular development because they usually entail microtom-based sectioning. This is of special relevance when performing screens aimed identifying new genes involved in adjusting the process to specific environmental factors. However, reverse genetic approaches may be useful and, by including experimental approaches based on natural variation and Genome-Wide Association Studies (GWAS), it might be possible to identify not only new regulators but also natural alleles for already known vascular developmental regulators key for adapting vascular development to specific habitats. In this respect, recent works that used GWAS-guided reverse genetics approaches have identified XYLEM NAC-DOMAIN1 (XND1) as a negative regulator of hydraulic conductivity that also affects vascular anatomical variation [148] and, as mentioned above, SOBIR1/EVR as a new regulator of the timing for fiber differentiation [98]. These are two clear examples of how natural variation-mediated identification of either new genes or allele variants for previously known genes may provide new tools for biotechnological approaches as well as insights into our understanding about the adaptation mechanisms in the process. At a higher order scale, experimenting with key species in the evolutionary clades of vascular plants may reveal which environmental factors have led to specific evolutionary aspects of the vascular development process and what genes have been relevant for such evolution. All this information, especially when validated in real natural conditions, might provide new, essential knowledge that can be used to artificially adapt our forest trees and crops to future environmental conditions or even to expand their geographical crop domain. 
In brief, we propose that understanding how plants adjust their vascular developmental program to environmental changes will enhance our understanding about the plasticity, adaptability and evolutionary history of the process. This knowledge may be a starting point for biotechnology applications aimed at ensuring biomass formation in a climate change context.

Acknowledgements Work in the authors' laboratories is supported by funds from the Spanish Ministry of Science and Universities (BIO2016-79147-R to JA, and BFU2016-80621-P to MAB). JA holds a Ramón y Cajal contract (RYC-2014-15752). We are deeply grateful to Debra Westall (Universitat Politècnica de València) for revising the manuscript. Due to space limitations, not all relevant publications could be included in this review.

\section{References}

1. Bowman JL, Kohchi T, Yamato KT, Jenkins J, Shu S, Ishizaki K et al (2017) Insights into land plant evolution garnered from the Marchantia polymorpha genome. Cell 171(2):287-304. https:// doi.org/10.1016/j.cell.2017.09.030(Epub 2017/10/07. PubMed PMID: 28985561)

2. Lucas WJ, Groover A, Lichtenberger R, Furuta K, Yadav SR, Helariutta $\mathrm{Y}$ et al (2013) The plant vascular system: evolution, development and functions. J Integr Plant Biol 55(4):294-388. https://doi.org/10.1111/jipb.12041(Epub 2013/03/07. PubMed PMID: 23462277)

3. Nelson T, Dengler N (1997) Leaf vascular pattern formation. Plant Cell 9(7):1121-1135. https://doi.org/10.1105/ tpc.9.7.1121(Epub 1997/07/01. PubMed PMID: 12237378; PubMed Central PMCID: PMCPMC156985)

4. Agusti J, Greb T (2013) Going with the wind-adaptive dynamics of plant secondary meristems. Mech Dev 130(1):34-44. https://doi.org/10.1016/j.mod.2012.05.011(Epub 2012/06/14. PubMed PMID: 22691403; PubMed Central PMCID: PMCPMC3560032)

5. Esau K (1961) Anatomy of seed plants. Wiley, New York

6. Spicer R, Groover A (2010) Evolution of development of vascular cambia and secondary growth. New Phytol 186(3):577-592. https://doi.org/10.1111/j.1469-8137.2010.03236.x

7. Ruonala R, Ko D, Helariutta Y (2017) Genetic networks in plant vascular development. Annu Rev Genet 51:335-359. https://doi. org/10.1146/annurev-genet-120116-024525(Epub 2017/09/12. PubMed PMID: 28892639)

8. Cano-Delgado A, Lee JY, Demura T (2010) Regulatory mechanisms for specification and patterning of plant vascular tissues. Annu Rev Cell Dev Biol 26:605-637. https://doi.org/10.1146/ annurev-cellbio-100109-104107(Epub 2010/07/02. PubMed PMID: 20590454)

9. Berleth T, Jurgens G (1993) The role of the monopteros gene in organising the basal body region of the Arabidopsis embryo. Development 118(2):575-587

10. Hartke CS, Berleth T (1998) The Arabidopsis gene MONOPTEROS encodes a transcription factor mediating embryo axis formation and vascular development. EMBO J 17:1405-1411

11. Busse JS, Evert RF (1999) Pattern of differentiation of the first vascular elements in the embryo and seedling of Arabidopsis thaliana. Int J Plant Sci 160:1-13

12. Mayer U, Ruiz RAT, Berleth T, Miséra S, Jürgens G (1991) Mutations affecting body organization in the Arabidopsis embryo. Nature 353(6343):402-407. https://doi.org/10.1038/353402a0
13. Wenzel CL, Schuetz M, Yu Q, Mattsson J (2007) Dynamics of MONOPTEROS and PIN-FORMED1 expression during leaf vein pattern formation in Arabidopsis thaliana. Plant $\mathrm{J}$ 49(3):387-398. https://doi.org/10.1111/j.1365-313X.2006.02977 .x(Epub 2007/01/16. PubMed PMID: 17217464)

14. Weijers D, Schlereth A, Ehrismann JS, Schwank G, Kientz M, Jurgens G (2006) Auxin triggers transient local signaling for cell specification in Arabidopsis embryogenesis. Dev Cell 10(2):265270. https://doi.org/10.1016/j.devce1.2005.12.001(Epub 2006/02/07. PubMed PMID: 16459305)

15. Hamann T, Benkova E, Baurle I, Kientz M, Jurgens G (2002) The Arabidopsis BODENLOS gene encodes an auxin response protein inhibiting MONOPTEROS-mediated embryo patterning. Genes Dev 16(13):1610-1615. https://doi.org/10.1101/ gad.229402(Epub 2002/07/09. PubMed PMID: 12101120; PubMed Central PMCID: PMCPMC186366)

16. Hamann T, Mayer U, Jurgens G (1999) The auxin-insensitive bodenlos mutation affects primary root formation and apicalbasal patterning in the Arabidopsis embryo. Development 126(7):1387-1395 (Epub 1999/03/09. PubMed PMID: 10068632)

17. Kepinski S, Leyser O (2005) The Arabidopsis F-box protein TIR1 is an auxin receptor. Nature 435(7041):446-451. https ://doi.org/10.1038/nature03542(Epub 2005/05/27. PubMed PMID: 15917798)

18. Schlereth A, Moller B, Liu W, Kientz M, Flipse J, Rademacher EH et al (2010) MONOPTEROS controls embryonic root initiation by regulating a mobile transcription factor. Nature 464(7290):913-916. https://doi.org/10.1038/nature08836(Epub 2010/03/12. PubMed PMID: 20220754)

19. Rashotte AM, Mason MG, Hutchison CE, Ferreira FJ, Schaller GE, Kieber JJ (2006) A subset of Arabidopsis AP2 transcription factors mediates cytokinin responses in concert with a two-component pathway. Proc Natl Acad Sci USA 103(29):11081-11085. https://doi.org/10.1073/pnas.0602038103(Epub 2006/07/13. PubMed PMID: 16832061; PubMed Central PMCID: PMCPMC1544176)

20. Rybel De B, Moller B, Yoshida S, Grabowicz I, Barbier de Reuille P, Boeren S et al (2013) A bHLH complex controls embryonic vascular tissue establishment and indeterminate growth in Arabidopsis. Dev Cell 24(4):426-437. https://doi. org/10.1016/j.devcel.2012.12.013(Epub 2013/02/19. PubMed PMID: 23415953)

21. Vera-Sirera F, Rybel De B, Urbez C, Kouklas E, Pesquera M, Alvarez-Mahecha JC et al (2015) A bHLH-based feedback loop restricts vascular cell proliferation in plants. Dev Cell 35(4):432443. https://doi.org/10.1016/j.devce1.2015.10.022(Epub 2015/11/27. PubMed PMID: 26609958)

22. Miyashima S, Roszak P, Sevilem I, Toyokura K, Blob B, Heo JO et al (2019) Mobile PEAR transcription factors integrate positional cues to prime cambial growth. Nature 565(7740):490-494. https://doi.org/10.1038/s41586-018-0839-y(Epub 2019/01/11. PubMed PMID: 30626969)

23. Mahonen AP, Bonke M, Kauppinen L, Riikonen M, Bengey PN, Helariutta Y (2000) A novel two-component hybrid molecule regulates vascular morphogenesis of the Arabidopsis root. Genes Dev 14:2938-2943

24. Baum SF, Dubrovsky JG, Rost TL (2002) Apical organization and maturation of the cortex and vascular cylonder in Arabidopsis thaliana (Brassicaceae) roots. Am J Bot 89(6):908-920

25. Campbell L, Turner S (2017) Regulation of vascular cell division. J Exp Bot 68(1):27-43. https://doi.org/10.1093/jxb/erw44 8(Epub 2016/12/15. PubMed PMID: 27965363)

26. Dolan L, Janmaat K, Willemsen V, Linstead P, Poethig S, Roberts K, Scheres B (1993) Cellular organisation of the Arabidopsis thaliana root. Development 119(1):71-84 
27. Mellor N, Adibi M, El-Showk S, Rybel De B, King J, Mahonen AP et al (2017) Theoretical approaches to understanding root vascular patterning: a consensus between recent models. J Exp Bot 68(1):5-16. https://doi.org/10.1093/jxb/erw410(Epub 2016/11/12. PubMed PMID: 27837006)

28. Carlsbecker A, Lee JY, Roberts CJ, Dettmer J, Lehesranta S, Zhou J et al (2010) Cell signalling by microRNA165/6 directs gene dose-dependent root cell fate. Nature 465(7296):316321. https://doi.org/10.1038/nature08977(Epub 2010/04/23. PubMed PMID: 20410882; PubMed Central PMCID: PMCPMC2967782)

29. Ramachandran P, Wang G, Augstein F, Vries de J, Carlsbecker A (2018) Continuous root xylem formation and vascular acclimation to water deficit involves endodermal ABA signalling via miR165. Development. https://doi.org/10.1242/dev.15920 2(Epub 2018/01/24. PubMed PMID: 29361572)

30. Mahonen AP, Bishopp A, Higuchi M, Nieminen KM, Kinoshita K, Tormakangas K, Ikeda Y, Oka A, Kakimoto T, Helariutta Y (2006) Cytokinin signaling and its inhibitor AHP6 regulate cell fate during vascular development. Science 311:94-98

31. Mahonen AP, Higuchi M, Tormakangas K, Miyawaki K, Pischke MS, Sussman MR et al (2006) Cytokinins regulate a bidirectional phosphorelay network in Arabidopsis. Curr Biol 16(11):11161122. https://doi.org/10.1016/j.cub.2006.04.030(Epub 2006/06/07. PubMed PMID: 16753566)

32. Ohashi-Ito K, Saegusa M, Iwamoto K, Oda Y, Katayama $\mathrm{H}$, Kojima $\mathrm{M}$ et al (2014) A bHLH complex activates vascular cell division via cytokinin action in root apical meristem. Curr Biol 24(17):2053-2058. https://doi.org/10.1016/j. cub.2014.07.050(Epub 2014/08/19. PubMed PMID: 25131670)

33. Bishopp A, Lehesranta S, Vaten A, Help H, El-Showk S, Scheres B et al (2011) Phloem-transported cytokinin regulates polar auxin transport and maintains vascular pattern in the root meristem. Curr Biol 21(11):927-932. https://doi.org/10.1016/j. cub.2011.04.049(Epub 2011/05/31. PubMed PMID: 21620705)

34. Bishopp A, Help H, El-Showk S, Weijers D, Scheres B, Friml J et al (2011) A mutually inhibitory interaction between auxin and cytokinin specifies vascular pattern in roots. Curr Biol 21(11):917-926. https://doi.org/10.1016/j. cub.2011.04.017(Epub 2011/05/31. PubMed PMID: 21620702)

35. Rybel De B, Adibi M, Breda AS, Wendrich JR, Smit ME, Novak $\mathrm{O}$ et al (2014) Integration of growth and patterning during vascular tissue formation in Arabidopsis. Science 345(6197): 1255215. https://doi.org/10.1126/science.1255215(Epub 2014/08/12. PubMed PMID: 25104393)

36. Knott JM (2009) Biosynthesis of long-chain polyamines by crenarchaeal polyamine synthases from Hyperthermus butylicus and Pyrobaculum aerophilum. FEBS Lett 583(21):3519-3524. https://doi.org/10.1016/j.febslet.2009.10.014(Epub 2009/10/14. PubMed PMID: 19822146)

37. Knott JM, Romer P, Sumper M (2007) Putative spermine synthases from Thalassiosira pseudonana and Arabidopsis thaliana synthesize thermospermine rather than spermine. FEBS Lett 581(16):3081-3086. https://doi.org/10.1016/j.febsl et.2007.05.074(Epub 2007/06/15. PubMed PMID: 17560575)

38. Baima S, Forte V, Possenti M, Penalosa A, Leoni G, Salvi S et al (2014) Negative feedback regulation of auxin signaling by ATHB8/ACL5-BUD2 transcription module. Mol Plant 7(6):1006-1025. https://doi.org/10.1093/mp/ssu051(Epub 2014/04/30. PubMed PMID: 24777988)

39. Imai A, Hanzawa Y, Komura M, Yamamoto KT, Komeda Y, Takahashi T (2006) The dwarf phenotype of the Arabidopsis ac15 mutant is suppressed by a mutation in an upstream ORF of a bHLH gene. Development 133(18):3575-3585. https://doi. org/10.1242/dev.02535(Epub 2006/08/29. PubMed PMID: 16936072)
40. Katayama H, Iwamoto K, Kariya Y, Asakawa T, Kan T, Fukuda $\mathrm{H}$ et al (2015) A negative feedback loop controlling bHLH complexes is involved in vascular cell division and differentiation in the root apical meristem. Curr Biol 25(23):3144-3150. https://doi.org/10.1016/j.cub.2015.10.051(Epub 2015/12/01. PubMed PMID: 26616019)

41. Muniz L, Minguet EG, Singh SK, Pesquet E, Vera-Sirera F, Moreau-Courtois CL et al (2008) ACAULIS5 controls Arabidopsis xylem specification through the prevention of premature cell death. Development 135(15):2573-2582. https://doi. org/10.1242/dev.019349(Epub 2008/07/05. PubMed PMID: 18599510)

42. Milhinhos A, Prestele J, Bollhöner B, Matos A, Vera-Sirera F, Rambla JL et al (2013) Thermospermine levels are controlled by an auxin-dependent feedback loop mechanism in Populus xylem. Plant J 75(4):685-698

43. Sole-Gil A, Hernandez-Garcia J, Lopez-Gresa MP, Blazquez MA, Agusti J (2019) Conservation of thermospermine synthase activity in vascular and non-vascular plants. Front Plant Sci 10:663. https://doi.org/10.3389/fpls.2019.00663(Epub 2019/06/28. PubMed PMID: 31244864; PubMed Central PMCID: PMCPMC6579911)

44. Bonke M, Thitamadee S, Mahonen AP, Hauser MT, Helariutta Y (2003) APL regulates vascular tissue identity in Arabidopsis. Nature 426(6963):181-186. https://doi.org/10.1038/nature0210 O(Epub 2003/11/14. PubMed PMID: 14614507)

45. Truernit E, Bauby H, Dubreucq B, Grandjean O, Runions J, Barthelemy J et al (2008) High-resolution whole-mount imaging of three-dimensional tissue organization and gene expression enables the study of phloem development and structure in Arabidopsis. Plant Cell 20(6):1494-1503. https://doi.org/10.1105/ tpc.107.056069(Epub 2008/06/05. PubMed PMID: 18523061; PubMed Central PMCID: PMCPMC2483377)

46. Furuta KM, Yadav SR, Lehesranta S, Belevich I, Miyashima S, Heo JO et al (2014) Plant development. Arabidopsis NAC45/86 direct sieve element morphogenesis culminating in enucleation. Science 345(6199):933-937. https://doi.org/10.1126/scien ce.1253736(Epub 2014/08/02. PubMed PMID: 25081480)

47. Kondo Y, Nurani AM, Saito C, Ichihashi Y, Saito M, Yamazaki K, Mitsuda N, Ohme-Takagi M, Fukuda H (2016) Vascular cell induction culture system using Arabidopsis leaves (VISUAL) reveals the sequential differentiation of sieve element-like cells. Plant Cell 28(6):1250-1262. https://doi.org/10.1105/ tpc. 16.00027

48. Truernit E, Bauby H, Belcram K, Barthelemy J, Palauqui JC (2012) OCTOPUS, a polarly localised membrane-associated protein, regulates phloem differentiation entry in Arabidopsis thaliana. Development 139(137):1306-1315. https://doi.org/10.1242/ dev.072629(Epub 2012/03/08. PubMed PMID: 22395740)

49. Mouchel CF, Briggs GC, Hardtke CS (2004) Natural genetic variation in Arabidopsis identifies BREVIS RADIX, a novel regulator of cell proliferation and elongation in the root. Genes Dev 18(6):700-714. https://doi.org/10.1101/gad.1187704(Epub 2004/03/20. PubMed PMID: 15031265; PubMed Central PMCID: PMCPMC387244)

50. Rodriguez-Villalon A, Gujas B, Kang YH, Breda AS, Cattaneo $P$, Depuydt $S$ et al (2014) Molecular genetic framework for protophloem formation. Proc Natl Acad Sci USA 111(31):1155111556. https://doi.org/10.1073/pnas.1407337111(Epub 2014/07/23. PubMed PMID: 25049386; PubMed Central PMCID: PMCPMC4128119)

51. Marhava P, Bassukas AEL, Zourelidou M, Kolb M, Moret B, Fastner A et al (2018) A molecular rheostat adjusts auxin flux to promote root protophloem differentiation. Nature 558(7709):297-300. https://doi.org/10.1038/s4158 6-018-0186-z(Epub 2018/06/08. PubMed PMID: 29875411) 
52. Depuydt S, Rodriguez-Villalon A, Santuari L, Wyser-Rmili C, Ragni L, Hardtke CS (2013) Suppression of Arabidopsis protophloem differentiation and root meristem growth by CLE45 requires the receptor-like kinase BAM3. Proc Natl Acad Sci USA 110(17):7074-7079. https://doi.org/10.1073/pnas.12223 14110(Epub 2013/04/10. PubMed PMID: 23569225; PubMed Central PMCID: PMCPMC3637694)

53. Kang YH, Hardtke CS (2016) Arabidopsis MAKR5 is a positive effector of BAM3-dependent CLE45 signaling. EMBO Rep 17(8):1145-1154. https://doi.org/10.15252/embr.20164 2450(Epub 2016/06/30. PubMed PMID: 27354416; PubMed Central PMCID: PMCPMC4967951)

54. Breda AS, Hazak O, Schultz P, Anne P, Graeff M, Simon R et al (2019) Cellular insulator against CLE45 peptide signaling. Curr Biol 29(15):2501-2508. https://doi.org/10.1016/j. cub.2019.06.037(Epub 2019/07/23. PubMed PMID: 31327718)

55. Rodriguez-Villalon A, Gujas B, Wijk van R, Munnik T, Hardtke CS (2015) Primary root protophloem differentiation requires balanced phosphatidylinositol-4,5-biphosphate levels and systemically affects root branching. Development 142(8):1437-1446. https://doi.org/10.1242/dev.118364(Epub 2015/03/31. PubMed PMID: 25813544)

56. Gujas B, Cruz TMD, Kastanaki E, Vermeer JEM, Munnik T, Rodriguez-Villalon A (2017) Perturbing phosphoinositide homeostasis oppositely affects vascular differentiation in Arabidopsis thaliana roots. Development 144(19):3578-3589. https://doi. org/10.1242/dev.155788(Epub 2017/08/31. PubMed PMID: 28851711; PubMed Central PMCID: PMCPMC5665488)

57. Wallner E-S, Lopez-Salmeron V, Belevich I, Poschet G, Jung I, Grunwald K, Sevilem I, Jokitalo E, Hell R, Helariutta Y, Agusti J, Lebovka I, Greb T (2017) Strigolactone- and karrikin-independent SMXL proteins are central regulators of phloem formation. Curr Biol 27:1241-1247

58. Hickey LJ (1973) Classification of the architecture of dicotyledonous leaves. Am J Bot 60(1):17-33

59. Sachs T (1981) The control of the patterned differentiation of vascular tissues. Adv Bot Res 9:151-162

60. Sachs T (1989) The development of vascular networks during leaf development. Curr Top Plant Biochem Physiol 8:168-183

61. Mattsson J, Ckurshumova W, Berleth T (2003) Auxin signaling in Arabidopsis leaf vascular development. Plant Physiol 131(3):1327-1339. https://doi.org/10.1104/pp.013623(Epub 2003/03/20. PubMed PMID: 12644682; PubMed Central PMCID: PMCPMC166892)

62. Scarpella E, Marcos D, Friml J, Berleth T (2006) Control of leaf vascular patterning by polar auxin transport. Genes Dev 20(8):1015-1027. https://doi.org/10.1101/gad.1402406(Epub 2006/04/19. PubMed PMID: 16618807; PubMed Central PMCID: PMCPMC1472298)

63. Donner TJ, Sherr I, Scarpella E (2009) Regulation of preprocambial cell state acquisition by auxin signaling in Arabidopsis leaves. Development 136(19):3235-3246. https://doi. org/10.1242/dev.037028(Epub 2009/08/28. PubMed PMID: 19710171)

64. Emery JF, Floyd SK, Alvarez J, Eshed Y, Hawker NP, Izhaki A et al (2003) Radial patterning of Arabidopsis shoots by class III HD-ZIP and KANADI genes. Curr Biol 13(20):1768-1774 (Epub 2003/10/17. PubMed PMID: 14561401)

65. Fisher K, Turner S (2007) PXY, a receptor-like kinase essential for maintaining polarity during plant vascular-tissue development. Curr Biol 17(12):1061-1066. https://doi.org/10.1016/j. cub.2007.05.049

66. Hirakawa Y, Shinohara H, Kondo Y, Inoue A, Nakanomyo I, Ogawa $\mathrm{M}$ et al (2008) Non-cell-autonomous control of vascular stem cell fate by a CLE peptide/receptor system. Proc Natl Acad
Sci 105(39):15208-15213. https://doi.org/10.1073/pnas.08084 44105

67. Etchells JP, Provost CM, Mishra L, Turner SR (2013) WOX4 and WOX14 act downstream of the PXY receptor kinase to regulate plant vascular proliferation independently of any role in vascular organisation. Development 140(10):89. https://doi.org/10.1242/ dev.091314

68. Hirakawa Y, Kondo Y, Fukuda H (2010) TDIF peptide signaling regulates vascular stem cell proliferation via the WOX4 homeobox gene in arabidopsis. Plant Cell 22(8):2618-2629. https:// doi.org/10.1105/tpc.110.076083

69. Ito Y, Nakanomio I, Motose H, Iwamoto K, Sawa S, Dohmae N, Fukuda H (2006) Dodeca-CLE peptides as suppressors of plant stem cell differentiation. Science 313(5788):842-855. https://doi. org/10.1126/science. 1128436

70. Turner S, Sieburth LE (2003) Vascular patterning. Arabidopsis Book 2:e0073. https://doi.org/10.1199/tab.0073(Epub 2003/01/01. PubMed PMID: 22303224; PubMed Central PMCID: PMCPMC3243335)

71. Courtois-Moreau CL, Pesquet E, Sjodin A, Muñiz L, Bollhoner B, Kaneda M, Samuels L, Jansson S, Tuominen H (2009) A unique program for cell death in xylem fibers of Populus stem. Plant J 58:260-274. https://doi.org/10.1111/j.1365313X.2008.03777.x

72. Ohashi-Ito K, Oda Y, Fukuda H (2010) Arabidopsis VASCULAR-RELATED NAC-DOMAIN6 directly regulates the genes that govern programmed cell death and secondary wall formation during xylem differentiation. Plant Cell 22(10):3461-3473

73. Ikematsu S, Tasaka M, Torii KU, Uchida N (2017) ERECTAfamily receptor kinase genes redundantly prevent premature progression of secondary growth in the Arabidopsis hypocotyl. New Phytol 213:1697-1709

74. Fischer U, Teichmann T (2017) The ERECTA and ERECTA-like genes control a developmental shift during xylem formation in Arabidopsis. New Phytol 213:1562-1563

75. Felipo-Benavent A, Urbez C, Blanco-Tourinan N, Serrano-Mislata A, Baumberger N, Achard P et al (2018) Regulation of xylem fiber differentiation by gibberellins through DELLA-KNAT1 interaction. Development 145(23):89. https://doi.org/10.1242/ dev.164962(Epub 2018/11/06. PubMed PMID: 30389856)

76. Liebsch D, Sunaryo W, Holmlund M, Norberg M, Zhang J, Hall HC, Helizon H, Jin X, Helariutta Y, Nilsson O, Polle A, Fischer U (2014) Class I KNOX transcription factors promote differentiation of cambial derivatives into xylem fibers in the Arabidopsis hypocotyl. Development 141:4311-4319

77. Milhinhos A, Vera-Sirera F, Blanco-Tourinan N, Mari-Carmona C, Carrio-Segui A, Forment J et al (2019) SOBIR1/EVR prevents precocious initiation of fiber differentiation during wood development through a mechanism involving BP and ERECTA. Proc Natl Acad Sci USA. https://doi.org/10.1073/pnas.1807863116 (Epub 2019/08/25. PubMed PMID: 31444299)

78. Mitsuda N, Iwase A, Yamamoto H, Yoshida M, Seki M, Shinozaki K, Ohme-Takagi M (2007) NAC transcription factors, NST1 and NST3, are key regulators of the formation of secondary walls in woody tissues of Arabidopsis. Plant Cell 19(1):270-280

79. Zhong R, Demura T, Ye ZH (2006) SND1, a NAC domain transcription factor, is a key regulator of secondary wall synthesis in fibers of Arabidopsis. Plant Cell 18(11):3158-3170

80. Siebers T, Catarino B, Agusti J (2017) Identification and expression analyses of new potential regulators of xylem development and cambium activity in cassava (Manihot esculenta). Planta 245(3):539-548. https://doi.org/10.1007/s00425-016-2623-2

81. Taylor-Teeples M, Lin L, Lucas de M, Turco G, Toal TW, Gaudinier A et al (2015) An Arabidopsis gene regulatory network for secondary cell wall synthesis. Nature 517(7536):7571-7575. https://doi.org/10.1038/nature1409 
9(Epub 2014/12/24. PubMed PMID: 25533953; PubMed Central PMCID: PMCPMC4333722)

82. Chaffey N, Cholewa E, Regan S, Sundberg B (2002) Secondary xylem development in Arabidopsis: a model for wood formation. Physiol Plant 114(4):594-600

83. Ragni L, Nieminen K, Pacheco-Villalobos D, Sibout R, Schwechheimer C, Hardtke CS (2011) Mobile gibberellin directly stimulates Arabidopsis hypocotyl xylem expansion. Plant Cell 23(4):1322-1336. https://doi.org/10.1105/ tpc. 111.084020

84. Agusti J, Lichtenberger R, Schwarz M, Nehlin L, Greb T (2011) Characterization of transcriptome remodeling during cambium formation identifies MOL1 and RUL1 as opposing regulators of secondary growth. PLoS Genet 7(2): e1001312

85. Thamm A, Sanegre-Sans S, Paisley J, Meader S, Milhinhos A, Contera $\mathrm{S}$ et al (2019) A simple mathematical model of allometric exponential growth describes the early three-dimensional growth dynamics of secondary xylem in Arabidopsis roots. $\mathrm{R}$ Soc Open Sci. https://doi.org/10.1098/rsos.190126

86. Etchells JP, Mishra L, Kumar M, Campbell L, Turner SR (2015) Wood formation in trees is increased by manipulating PXYregulated cell division. Curr Biol 25(8):1050-1055. https://doi. org/10.1016/j.cub.2015.02.023

87. Brackmann K, Qi J, Gebert M, Jouannet V, Schlamp T, Grunwald $\mathrm{K}$ et al (2018) Spatial specificity of auxin responses coordinates wood formation. Nat Commun 9(1):875. https://doi.org/10.1038/ s41467-018-03256-2(Epub 2018/03/02. PubMed PMID: 29491423; PubMed Central PMCID: PMCPMC5830446)

88. Han S, Cho H, Noh J, Qi J, Jung H-J, Nam H, Lee S, Hwang D, Greb T, Hwang I (2018) BIL1-mediated MP phosphorylation integrates PXY and cytokinin signalling in secondary growth. Nat Plants 4:605-614. https://doi.org/10.1038/s4147 7-018-0180-3

89. Smetana O, Makila R, Lyu M, Amiryousefi A, Sanchez Rodriguez F, Wu MF et al (2019) High levels of auxin signalling define the stem-cell organizer of the vascular cambium. Nature 565(7740):485-489. https://doi.org/10.1038/s41586-018-08370(Epub 2019/01/11. PubMed PMID: 30626967)

90. Snow R (1935) Activation of cambial growth by pure hormones. New Phytol 34(5):14

91. Bhalerao RP, Fischer U (2014) Auxin gradients across woodinstructive or incidental? Physiol Plant 151(1):43-51. https:// doi.org/10.1111/ppl.12134(Epub 2013/11/30. PubMed PMID: 24286229)

92. Tuominen H, Puech L, Fink S, Sundberg B (1997) A radial concentration gradient of indole-3-acetic acid is related to secondary xylem development in hybrid aspen. Plant Physiol 115(2):577-585. https://doi.org/10.1104/pp.115.2.577(Epub 2002/09/12. PubMed PMID: 12223825; PubMed Central PMCID: PMCPMC158517)

93. Uggla C, Mellerowicz EJ, Sundberg B (1998) Indole-3-acetic acid controls cambial growth in scots pine by positional signaling. Plant Physiol 117(1):113-121. https://doi.org/10.1104/ pp.117.1.113(Epub 1998/05/22. PubMed PMID: 9576780; PubMed Central PMCID: PMCPMC34994)

94. Mazur E, Kurczynska EU (2012) Rays, intrusive growth, and storied cambium in the inflorescence stems of Arabidopsis thaliana (L.) Heynh. Protoplasma 249(1):217-220. https ://doi.org/10.1007/s00709-011-0266-5(Epub 2011/02/12. PubMed PMID: 21311923; PubMed Central PMCID: PMCPMC3249544)

95. Mazur E, Kurczynska EU, Friml J (2014) Cellular events during interfascicular cambium ontogenesis in inflorescence stems of Arabidopsis. Protoplasma 251(5):1125-1139. https://doi. org/10.1007/s00709-014-0620-5(Epub 2014/02/15. PubMed PMID: 24526327)
96. Nilsson J, Karlberg A, Antti H, Lopez-Vernaza M, Mellerowicz E, Perrot-Rechenmann C et al (2008) Dissecting the molecular basis of the regulation of wood formation by auxin in hybrid aspen. Plant Cell 20(4):843-855. https://doi.org/10.1105/ tpc.107.055798(Epub 2008/04/22. PubMed PMID: 18424614; PubMed Central PMCID: PMCPMC2390731)

97. Suer S, Agusti J, Sanchez J, Schwarz M, Greb T (2011) WOX4 imparts auxin responsiveness to cambium cells in Arabidopsis. Plant Cell 23(9):3247-3259. https://doi.org/10.1105/ tpc. 111.087874

98. Ko J-H, Han K-H, Park S, Yang J (2004) Plant body weightinduced secondary growth in Arabidopsis and its transcription phenotype revealed by whole-transcriptome profiling. Plant Physiol 135(2):1069-1083. https://doi.org/10.1104/ pp.104.038844

99. Little CHA, MacDonald JE, Olsson O (2002) Involvement of indole-3-acetic acid in fascicular and interfascicular cambial growth and interfascicular extraxylary fiber differentiation in Arabidopsis thaliana inflorescence stems. Int J Plant Sci 163:519-529

100. Agusti J, Herold S, Schwarz M, Sanchez P, Ljung K, Dun EA, Brewer PB, Beveridge CA, Sieberer T, Sehr EM, Greb T (2011) Strigolactone signaling is required for auxin-dependent stimulation of secondary growth in plants. PNAS 108(50):6. https://doi.org/10.1073/pnas.1111902108

101. Matsumoto-Kitano M, Kusumoto T, Tarkowski P, KinoshitaTsujimura K, Vaclavikova K, Miyawaki K et al (2008) Cytokinins are central regulators of cambial activity. Proc Natl Acad Sci USA 105(50):20027-20031. https://doi.org/10.1073/ pnas.0805619105(Epub 2008/12/17. PubMed PMID: 19074290; PubMed Central PMCID: PMCPMC2605004)

102. Smet W, Sevilem I, Luis Balaguer de MA, Wybouw B, Mor E, Miyashima S et al (2019) DOF2.1 controls cytokinindependent vascular cell proliferation downstream of TMO5/ LHW. Curr Biol 29(3):520-529. https://doi.org/10.1016/j. cub.2018.12.041(Epub 2019/01/29. PubMed PMID: 30686737; PubMed Central PMCID: PMCPMC6370950)

103. Eriksson ME, Israelsson M, Olsson O, Moritz T (2000) Increased gibberellin biosynthesis in transgenic trees promotes growth, biomass production and xylem fiber length. Nat Biotechnol 18(7):784-788. https://doi.org/10.1038/77355(Epub 2000/07/11. PubMed PMID: 10888850)

104. Sehr EM, Agusti J, Lehner R, Farmer EE, Schwarz M, Greb T (2010) Analysis of secondary growth in the Arabidopsis shoot reveals a positive role of jasmonate signalling in cambium formation. Plant J 63(5):811-822. https://doi.org/10.1111/j.1365313X.2010.04283.x

105. Etchells JP, Provost CM, Turner SR (2012) Plant vascular cell division is maintained by an interaction between PXY and ethylene signalling. PLoS Genet 8(11):e1002997. https ://doi.org/10.1371/journal.pgen.1002997(Epub 2012/11/21. PubMed PMID: 23166504; PubMed Central PMCID: PMCPMC3499249)

106. Campbell L, Etchells JP, Cooper M, Kumar M, Turner SR (2018) An essential role for abscisic acid in the regulation of xylem fibre differentiation. Development. https://doi. org/10.1242/dev.161992(Epub 2018/10/26. PubMed PMID: 30355726)

107. Iakimova ET, Woltering EJ (2017) Xylogenesis in zinnia (Zinnia elegans) cell cultures: unravelling the regulatory steps in a complex developmental programmed cell death event. Planta 245(4):681-705. https://doi.org/10.1007/s00425-017-26561(Epub 2017/02/15. PubMed PMID: 28194564; PubMed Central PMCID: PMCPMC5357506)

108. Sperry JS, Hacke UG, Pittermann J (2006) Size and function in conifer tracheids and angiosperm vessels. Am J Bot 
93(10):1490-1500. https://doi.org/10.3732/ajb.93.10.1490(Epub 2006/10/01. PubMed PMID: 21642096)

109. Agusti J, Zapater M, Iglesias DJ, Cercós M, Tadeo FR, Talón M (2007) Differential expression of putative 9-cis-epoxycarotenoid dioxygenases and abscisic acid accumulation in water stressed vegetative and reproductive tissues of citrus. Plant Sci 172(1):85-94

110. Bloch D, Puli MR, Mosquna A, Yalovsky S (2019) Abiotic stress modulates root patterning via ABA-regulated microRNA expression in the endodermis initials. Development 146(17):89. https:// doi.org/10.1242/dev.177097(Epub 2019/08/11. PubMed PMID: 31399468)

111. Agusti J, Gimeno J, Merelo P, Serrano R, Cercos M, Conesa A et al (2012) Early gene expression events in the laminar abscission zone of abscission-promoted citrus leaves after a cycle of water stress/rehydration: involvement of CitbHLH1. J Exp Bot 63(17):6079-6091. https://doi.org/10.1093/jxb/ers270(Epub 2012/10/03. PubMed PMID: 23028022; PubMed Central PMCID: PMCPMC3481208)

112. Gomez-Cadenas A, Tadeo FR, Talon M, Primo-Millo E (1996) Leaf abscission induced by ethylene in water-stressed intact seedlings of Cleopatra mandarin requires previous abscisic acid accumulation in roots. Plant Physiol 112(1):401-408. https://doi. org/10.1104/pp.112.1.401(Epub 1996/09/01. PubMed PMID: 12226398; PubMed Central PMCID: PMCPMC157962)

113. Arend M, Fromm J (2007) Seasonal change in the drought response of wood cell development in poplar. Tree Physiol 27(7):985-992. https://doi.org/10.1093/treephys/27.7.985(Epub 2007/04/04. PubMed PMID: 17403651)

114. Fonti P, Heller O, Cherubini P, Rigling A, Arend M (2013) Wood anatomical responses of oak saplings exposed to air warming and soil drought. Plant Biol (Stuttgart, Germany) 15(Suppl 1):210 219. https://doi.org/10.1111/j.1438-8677.2012.00599.x(Epub 2012/05/23. PubMed PMID: 22612857)

115. Eldhuset TD, Nagy NE, Volarik D, Borja I, Gebauer R, Yakovlev IA, Krokene P (2013) Drought affects tracheid structure, dehydrin expression, and above- and belowground growth in 5-yearold Norway spruce. Plant Soil 366:305-320

116. Rita A, Cherubini P, Leonardi S, Todaro L, Borghetti M (2015) Functional adjustments of xylem anatomy to climatic variability: insights from long-term Ilex aquifolium tree-ring series. Tree Physiol 35(8):817-828. https://doi.org/10.1093/treephys/tpv05 5(Epub 2015/07/05. PubMed PMID: 26142450)

117. Pegler JL, Oultram JMJ, Grof CPL, Eamens AL (2019) Profiling the abiotic stress responsive microRNA landscape of Arabidopsis thaliana. Plants 8(3):89. https://doi.org/10.3390/plants8030 058(Epub 2019/03/13. PubMed PMID: 30857364; PubMed Central PMCID: PMCPMC6473545)

118. Zhao Y, Lin S, Qiu Z, Cao D, Wen J, Deng X et al (2015) MicroRNA857 is involved in the regulation of secondary growth of vascular tissues in Arabidopsis. Plant Physiol 169(4):25392552. https://doi.org/10.1104/pp.15.01011(Epub 2015/10/30. PubMed PMID: 26511915; PubMed Central PMCID: PMCPMC4677895)

119. Tang S, Dong Y, Liang D, Zhang Z, Ye C-Y, Shuai P, Han X, Zhao Y, Yin W, Xia X (2015) Analysis of the drought stressresponsive transcriptome of black cottonwood (Populus trichocarpa) using deep RNA sequencing. Plant Mol Biol Rep 33:424-438

120. Davies WJKG, Hartung W (2015) Long-distance ABA signalling and its relation to other signalling pathways in the detection of soil drying and the mediation of the plant's response to drought. J Plant Growth Regul 24:285-295

121. Bano ADK, Bettin D, Hahn H (1993) Abscisic acid and cytokinins as possible root-to-shoot signals in xylem sap of rice plants in drying soils. Funct Plant Biol 20:109-115
122. Nishiyama R, Watanabe Y, Fujita Y, Le DT, Kojima M, Werner $\mathrm{T}$ et al (2011) Analysis of cytokinin mutants and regulation of cytokinin metabolic genes reveals important regulatory roles of cytokinins in drought, salt and abscisic acid responses, and abscisic acid biosynthesis. Plant Cell 23(6):2169-2183. https://doi.org/10.1105/tpc.111.087395(Epub 2011/07/02. PubMed PMID: 21719693; PubMed Central PMCID: PMCPMC3160038)

123. Jang G, Chang SH, Um TY, Lee S, Kim JK, Choi YD (2017) Antagonistic interaction between jasmonic acid and cytokinin in xylem development. Sci Rep 7(1):10212. https://doi.org/10.1038/ s41598-017-10634-1(Epub 2017/09/02. PubMed PMID: 28860478; PubMed Central PMCID: PMCPMC5579306)

124. Ollas de C, Arbona V, Gomez-Cadenas A (2015) Jasmonoyl isoleucine accumulation is needed for abscisic acid build-up in roots of Arabidopsis under water stress conditions. Plant Cell Environ 38(10):2157-2170. https://doi.org/10.1111/pce.12536 (Epub 2015/03/20. PubMed PMID: 25789569)

125. Sellami S, Le Hir R, Thorpe MR, Aubry E, Wolff N, Vilaine F et al (2019) Arabidopsis natural accessions display adaptations in inflorescence growth and vascular anatomy to withstand high salinity during reproductive growth. Plants (Basel, Switzerland). https://doi.org/10.3390/plants8030061(Epub 2019/03/14. PubMed PMID: 30862126; PubMed Central PMCID: PMCPMC6473358)

126. Shinohara S, Okamoto T, Motose H, Takahashi T (2019) Salt hypersensitivity is associated with excessive xylem development in a thermospermine-deficient mutant of Arabidopsis thaliana. Plant J. https://doi.org/10.1111/tpj.14448(Epub 2019/07/02. PubMed PMID: 31257654)

127. Escalante-Perez M, Lautner S, Nehls U, Selle A, Teuber M, Schnitzler JP et al (2009) Salt stress affects xylem differentiation of grey poplar (Populus $\times$ canescens). Planta 229(2):299-309. https://doi.org/10.1007/s00425-008-0829-7(Epub 2008/10/24. PubMed PMID: 18946679)

128. Sanchez-Aguayo I, Rodriguez-Galan JM, Garcia R, Torreblanca J, Pardo JM (2004) Salt stress enhances xylem development and expression of $S$-adenosyl-L-methionine synthase in lignifying tissues of tomato plants. Planta 220(2):278-285. https://doi. org/10.1007/s00425-004-1350-2(Epub 2004/08/24. PubMed PMID: 15322882)

129. Barzegargolchini B, Movafeghi A, Dehestani A, Mehrabanjoubani P (2017) Increased cell wall thickness of endodermis and protoxylem in Aeluropus littoralis roots under salinity: the role of LAC4 and PER64 genes. J Plant Physiol 218:127-134. https:// doi.org/10.1016/j.jplph.2017.08.002(Epub 2017/08/19. PubMed PMID: 28818759)

130. Wessels B, Seyfferth C, Escamez S, Vain T, Antos K, Vahala $J$ et al (2019) An AP2/ERF transcription factor ERF139 coordinates xylem cell expansion and secondary cell wall deposition. New Phytol. https://doi.org/10.1111/nph.15960(Epub 2019/05/28. PubMed PMID: 31125440)

131. Guo H, Wang Y, Wang L, Hu P, Wang Y, Jia Y et al (2017) Expression of the MYB transcription factor gene BplMYB46 affects abiotic stress tolerance and secondary cell wall deposition in Betula platyphylla. Plant Biotechnol J 15(1):107-121. https:// doi.org/10.1111/pbi.12595(Epub 2016/07/03. PubMed PMID: 27368149; PubMed Central PMCID: PMCPMC5253473)

132. Begum S, Nakaba S, Yamagishi Y, Oribe Y, Funada R (2013) Regulation of cambial activity in relation to environmental conditions: understanding the role of temperature in wood formation of trees. Physiol Plant 147(1):46-54. https://doi.org/10.1 111/j.1399-3054.2012.01663.x(Epub 2012/06/12. PubMed PMID: 22680337)

133. Druart N, Johansson A, Baba K, Schrader J, Sjodin A, Bhalerao RR et al (2007) Environmental and hormonal regulation of 
the activity-dormancy cycle in the cambial meristem involves stage-specific modulation of transcriptional and metabolic networks. Plant J 50(4):557-573. https://doi.org/10.1111/j.1365313X.2007.03077.x(Epub 2007/04/11. PubMed PMID: 17419838)

134. Li WF, Ding Q, Chen JJ, Cui KM, He XQ (2009) Induction of PtoCDKB and PtoCYCB transcription by temperature during cambium reactivation in Populus tomentosa Carr. J Exp Bot 60(9):2621-2630. https://doi.org/10.1093/jxb/erp108(Epub 2009/05/06. PubMed PMID: 19414499; PubMed Central PMCID: PMCPMC2692011)

135. Nick P (2008) Microtubules as sensors for abiotic stimuli. In: Nick P (ed) Plant cell monographs: plant microtubules. Springer, Berlin, pp 175-203

136. Rajangam AS, Kumar M, Aspeborg H, Guerriero G, Arvestad L, Pansri P et al (2008) MAP20, a microtubule-associated protein in the secondary cell walls of hybrid aspen, is a target of the cellulose synthesis inhibitor 2,6-dichlorobenzonitrile. Plant Physiol 148(3):1283-1294. https://doi.org/10.1104/pp.108.12191 3(Epub 2008/09/23. PubMed PMID: 18805954; PubMed Central PMCID: PMCPMC2577246)

137. Stewart JJ, Demmig-Adams B, Cohu CM, Wenzl CA, Muller O, Adams WW 3rd (2016) Growth temperature impact on leaf form and function in Arabidopsis thaliana ecotypes from northern and southern Europe. Plant Cell Environ 39(7):1549-1558. https:// doi.org/10.1111/pce.12720(Epub 2016/02/03. PubMed PMID: 26832121)

138. Jung CG, Hwang SG, Park YC, Park HM, Kim DS, Park DH et al (2015) Molecular characterization of the cold- and heatinduced Arabidopsis PXL1 gene and its potential role in transduction pathways under temperature fluctuations. J Plant Physiol 176:138-146. https://doi.org/10.1016/j.jplph.2015.01.001(Epub 2015/01/21. PubMed PMID: 25602612)

139. Yuan Y, Teng Q, Zhong R, Ye ZH (2013) The Arabidopsis DUF231 domain-containing protein ESK1 mediates 2-O- and 3-O-acetylation of xylosyl residues in xylan. Plant Cell Physiol 54(7):1186-1199. https://doi.org/10.1093/pcp/pct070(Epub 2013/05/11. PubMed PMID: 23659919)

140. Lefebvre V, Fortabat MN, Ducamp A, North HM, Maia-Grondard A, Trouverie J et al (2011) ESKIMO1 disruption in Arabidopsis alters vascular tissue and impairs water transport. PLoS One 6(2):e16645. https://doi.org/10.1371/journal.pone.00166 45(Epub 2011/03/17. PubMed PMID: 21408051; PubMed Central PMCID: PMCPMC3052256)

141. Xin Z, Mandaokar A, Chen J, Last RL, Browse J (2007) Arabidopsis ESK1 encodes a novel regulator of freezing tolerance. Plant J 49(5):786-799. https://doi.org/10.1111/j.1365313X.2006.02994.x(Epub 2007/02/24. PubMed PMID: 17316173)
142. Koizumi K, Yokoyama R, Nishitani K (2009) Mechanical load induces upregulation of transcripts for a set of genes implicated in secondary wall formation in the supporting tissue of Arabidopsis thaliana. J Plant Res 122(6):651-659. https://doi. org/10.1007/s10265-009-0251-7(Epub 2009/07/08. PubMed PMID: 19582540)

143. Love J, Bjorklund S, Vahala J, Hertzberg M, Kangasjarvi J, Sundberg B (2009) Ethylene is an endogenous stimulator of cell division in the cambial meristem of Populus. Proc Natl Acad Sci USA 106(14):5984-5989. https://doi.org/10.1073/pnas.08116 60106(Epub 2009/03/19. PubMed PMID: 19293381; PubMed Central PMCID: PMCPMC2657089)

144. Hellgren JM, Olofsson K, Sundberg B (2004) Patterns of auxin distribution during gravitational induction of reaction wood in poplar and pine. Plant Physiol 135(1):212-220. https://doi. org/10.1104/pp.104.038927(Epub 2004/05/04. PubMed PMID: 15122024; PubMed Central PMCID: PMCPMC429355)

145. De Zio E, Trupiano D, Karady M, Antoniadi I, Montagnoli A, Terzaghi M et al (2019) Tissue-specific hormone profiles from woody poplar roots under bending stress. Physiol Plant 165(1):101-113. https://doi.org/10.1111/ppl.12830(Epub 2018/09/07. PubMed PMID: 30187489)

146. Funada R, Miura T, Shimizu Y, Kinase T, Nakaba S, Kubo T et al (2008) Gibberellin-induced formation of tension wood in angiosperm trees. Planta 227(6):1409-1414. https://doi. org/10.1007/s00425-008-0712-6(Epub 2008/03/06. PubMed PMID: 18320214)

147. Landrein B, Kiss A, Sassi M, Chauvet A, Das P, Cortizo M et al (2015) Mechanical stress contributes to the expression of the STM homeobox gene in Arabidopsis shoot meristems. Elife 4:e07811. https://doi.org/10.7554/eLife.07811(Epub 2015/12/02. PubMed PMID: 26623515; PubMed Central PMCID: PMCPMC4666715)

148. Tang N, Shahzad Z, Lonjon F, Loudet O, Vailleau F, Maurel C (2018) Natural variation at XND1 impacts root hydraulics and trade-off for stress responses in Arabidopsis. Nat Commun 9(1):3884. https://doi.org/10.1038/s41467-018-06430-8 (Epub 2018/09/27. PubMed PMID: 30250259; PubMed Central PMCID: PMCPMC6155316)

Publisher's Note Springer Nature remains neutral with regard to jurisdictional claims in published maps and institutional affiliations. 